\title{
PR $0150-3$
}

DOE/FC/10225-1584

(DE84010496)

ON-SITE FIELD TESTS FOR STUDY OF LOW-RANK WESTERN

COAL FLY ASH

Technical Summary Report, Field Test No. 3, Big Brown Station

Electrostatic Precipitator

By

Robert S. Dahlin

Roy E. Bickelhaupt

Guillaume H. Marchante, Jr.

John P. Gooch

February 1984

Work Performed Under Contract No. AC18-80FC10225

Southern Research Institute

Birmingham, Alabama

Technical Information Center

Office of Scientific and Technical Information

United States Department of Energy 


\section{DISCLAIMER}

This report was prepared as an account of work sponsored by an agency of the United States Government. Neither the United States Government nor any agency Thereof, nor any of their employees, makes any warranty, express or implied, or assumes any legal liability or responsibility for the accuracy, completeness, or usefulness of any information, apparatus, product, or process disclosed, or represents that its use would not infringe privately owned rights. Reference herein to any specific commercial product, process, or service by trade name, trademark, manufacturer, or otherwise does not necessarily constitute or imply its endorsement, recommendation, or favoring by the United States Government or any agency thereof. The views and opinions of authors expressed herein do not necessarily state or reflect those of the United States Government or any agency thereof. 


\section{DISCLAIMER}

Portions of this document may be illegible in electronic image products. Images are produced from the best available original document. 


\title{
DISCLAIMER
}

\begin{abstract}
This report was prepared as an account of work sponsored by an agency of the United States Government. Neither the United States Government nor any agency thereof, nor any of their employees, makes any warranty, express or implied, or assumes any legal liability or responsibility for the accuracy, completeness, or usefulness of any information, apparatus, product, or process disclosed, or represents that its use would not infringe privately owned rights. Reference herein to any specific commercial product, process, or service by trade name, trademark, manufacturer, or otherwise does not necessarily constitute or imply its endorsement, recommendation, or favoring by the United States Government or any agency thereof. The views and opinions of authors expressed herein do not necessarily state or reflect those of the United States Government or any agency thereof.
\end{abstract}

This report has been reproduced directly from the best available copy.

Available from the National Technical Information Service, U. S. Department of Commerce, Springfield, Virginia 22161.

Price: Printed Copy A04

Microfiche A01

Codes are used for pricing all publications. The code is determined by the number of pages in the publication. Information pertaining to the pricing codes can be found in the current issues of the following publications, which are generally available in most libraries: Energy Research Abstracts (ERA); Government Reports Announcements and Index (GRA and I); Scientific and Technical Abstract Reports (STAR); and publication NTIS-PR-360 available from NTIS at the above address. 
Harvey M. Ness, Technical Project Officer Morgantown Energy Technology Center Grand Forks Project Office P.0. Box 7206, University Station Grand Forks, North Dakota 58202

PREPARED FOR THE

U.S. Department of Energy Under Contract No. DE-AC18-80FC10225 
THIS PAGE

WAS INTENTIONALLY

LEFT BLANK 
ABSTRACT

This report describes the results of field and laboratory studies of combined $\mathrm{NH}_{3}$ and $\mathrm{SO}_{3}$ conditioning at the Big Brown Station of Texas Utilities Generating Company. This unusual combination of conditioning agents is used routinely at the Big Brown Station in order to improve the performance of the cold-side electrostatic precipitators. EPRI is interested in the Big Brown Station from the standpoint of increasing the understanding of flue gas conditioning mechanisms by studying the dual conditioning system used at this plant. The Big Brown Station is of interest to DOE because of its applicability to DOE-sponsored efforts to develop a data base on particulate characteristics and particulate control technologies for low-rank Western coals.

The primary objectives of this field study were to evaluate the performance of one of the Big Brown precipitators, and to obtain data on the concentration, composition, and size distribution of the $f l y$ ash, as well as the composition of the flue gas and the overall and fractional collection efficiencies of the precipitator. The laboratory studies of the Big Brown fly ash were intended to further characterize the ash both pinsically and chemically, and to study the attenuation of the electrical resistivity of the ash assoclated with the surface film produced by the dual conditioning process and by the use of $\mathrm{SO}_{3}$ conditioning alone.

The Unit 2 precipitators, one of which was tested in this work, service a Combustion Fngineering pulverized coal-fired boiler having a nominal generating capacity of 575 MW. The unit fires a Wilcox group Texas lignite that is mined on site. The lignite fired during this test program had an average heating value of about $7000 \mathrm{Btu} / \mathrm{Lb}$ and $\mid$ an average ash content of about 178 on an as-received basis. Daily lignit.e samples showed considerable variability in the composition of the lignite during the test.

Flue gas analyses performed upstream and downstream of the $\mathrm{SO}_{3}$ injection probes indicated that about $5 \mathrm{ppm}$ of $\mathrm{SO}_{3}$ was produced from the coal and an additional $9 \mathrm{ppm}$ of $\mathrm{SO}_{3}$ was contributed by the injection system. The $\mathrm{SO}_{3}$ was injected ahead of the air preheater. The $\mathrm{NH}_{3}$ was injected between the air preheater and the precipitator 
at a rate of about $5 \mathrm{ppm}$. At the precipitator inlet, the measured $\mathrm{NH}_{3}$ and $\mathrm{SO}_{3}$ concentrations were both below $0.5 \mathrm{ppm}$. The $\mathrm{NH}_{4}{ }^{+}$content of the fly ash collected at the ESP inlet accounts for about 768 of the $\mathrm{NH}_{3}$ injected into the flue gas. At most, an additional 108 of the $\mathrm{NH}_{3}$ is left in the gas phase, so that about 148 is not accounted for. The $\mathrm{SO}_{4}^{-2}$ content of the fly ash is greater than expected for complete adsorption of $14 \mathrm{ppm}$ of $\mathrm{SO}_{3}$. This may be due to additional uptake of $\mathrm{so}_{3}$ by the ash while it resided in the mass train filter, and was exposed to additional flue gas. It is suggested that the dual conditioning system results in a surface film on the fly ash that probably consists of $\left(\mathrm{NH}_{4}\right)_{2} \mathrm{SO}_{4}$ and/Or $\mathrm{NH}_{4} \mathrm{HSO}_{4}$ dissolved in an aqueous solution of $\mathrm{H}_{2} \mathrm{SO}_{4}$, which results from the adsorption of the excess $\mathrm{SO}_{3}$ and water vapor.

Laboratory studies showed that the as-received ash (i.e., the ash with the surface film on $i t$ ) was more responsive to $\mathrm{SO}_{3}$ conditioning than was the same ash after it. had been heated to $450^{\circ} \mathrm{C}$ and the surface film had been driven off. This suggests that the presence of the $\mathrm{NH}_{3}$ served to make the ash more receptive to $\mathrm{SO}_{3} \mathrm{Condition-}$ ing. This may be attributed to a reduction in the vapor pressure of the surface film due to the dissclution of the ammonium compounds in the acid. However, additional work would be required to further investigate this theory. The laboratory studies also showed a significant increase in resistivity after an as-received ash sample was heated to $450^{\circ} \mathrm{C}$, and then brought back to the original temperature. This was attributed to the decomposition of the surface film, and the attendant loss of its beneficial effect on the electrical conduction process.

The overall performance of the Big Brown precipitator, in terms of collection efficiency and electrical operation, was quite good, especially considering its small size (SCA $\cong 166 \mathrm{ft}^{2} / \mathrm{kaCfm}$ ). The average mass efficiency determined by EPA Method 17 was about 98.58 with an average inlet mass loading of $6.64 \mathrm{gr} / \mathrm{dscf}$. A plot of collection efficiency versus particle size, based on cascade impactor measurements, showed a minimum at about $0.8 \mu \mathrm{m}$. Above $1 \mathrm{\mu m}$ the fractional efficiency curve was qualitatively consistent with theory. Well-behaved voltage-current curves were obtained for all of the $T-R$ sets tested. The electrical conditions were apparently not limited by the resistivity of the ash, which was measured in the laboratory to be about $1 \times 10^{10} \mathrm{ohm} \mathrm{cm}$ at $345^{\circ} \mathrm{F}$ and in the presence of about $0.3 \mathrm{ppm}$ of $\mathrm{so}_{3^{\circ}}$ The in situ resistivity measurements were higher, but they were deemed unreliable because they exhibited an inordinate degree of scatter in the data, and they were inconsistent with the electrical operating conditions of the precipitator. 
Given an ash resistivity of $1 \times 10^{10} \mathrm{chm} \mathrm{cm}$, and assuming 108 gas sneakage around the electrified regions of the ESP and a 258 normalized standard deviation on the gas flow, the predicted efficiency for the Big Brown precipitatcr cbtained by using a mathematical model was 98.58 , almost exactly equal to the average measured efficiency. This exact agreement is probably fortuitous, but it does indicate that there were no major mechanical problems with the precipitator. 
ACKNOWLEDGMENTS

The authors are indebted to Texas Utilities Generating Company and their personnel at the Big Brown station who provided assistance with this study. Special recognition should be given to: Mr. Tom Edling and Mr. Steve Payton, who served as our 1 iaisons with the plant personnel; Mr. Ed Platt, the Plant Manager; and Mr. Billie Bonner and Mr. Richard White, with the TuGco corprate offices.

The field test described in this report was performed by the Control Device Evaluation Section of Southern Research Institute, under the supervision of Mr. G. H. Marchant, Jr., with the assistance of personnel provided by Guardian Systems, Inc. The following Institute personnel participated in the field test: Messieurs R. S. Dahlin, W. R. Dickson, W. S. Hall, T. F. Hammond, C. V. Lindsey, S. C. Parsons, and M. R. Steele. Mr. Dickson also performed the chemical analyses and wrote the sections of this report dealing with the $\mathrm{SO}_{\mathrm{X}}$ and $\mathrm{NH}_{3}$ measurements and flue gas composition. Dr. R. E. Bickelhaupt supervised the laboratory resistivity work. This work was jointly funded by the U.S. Department of Energy under Contract No. DEAC18-80FC10225 and the Electric Power Researoh Institute under Contract No. RP724-2. The Project Managers were Dr. Ralph F. Altman of the Electric Power Research Inseleute and Dr. D. Richard Sears and Mr. Harvey M. Ness of the Department of Energy's Grand Forks Project Office. Dr. Sears is now associated with the University of North Dakota Energy Research Center. 
CONTENTS

ABSTRACT

iii

ACKNOWLEDGMENTS

vi

S EXECUTIVE SUMMARY

$s-1$

1 INTRODUCTION

$1-1$

2 SITE SELECTION AND DESCRIPTION

$2-1$

3 FIELD TEST RESULTS

3-1

Sampling and Measurement Activities

3-1

Characterization of Coal and Fly Ash

3-1

Method 17 Results and Mass Efficiency

$3-3$

Particle Size Distributions and Fraotional Efficiency

$3-4$

In Situ Resistivity and $\mathrm{SO}_{x}$ and $\mathrm{NH}_{3}$ Measurements

$3-13$

Five-Stage Cyclone Size Fractionation

3-17

Electrical Characteristics of ESP

3-19

4 LABORATORY CHARACTERIZATION OF FLY ASH

$4-1$

5 SUMMARY AND CONCLUSIONS

$5-1$

6 REFERENCES

$6-1$ 


\section{ILLUSTRATIONS}

\section{Figure}

2-1 Big Brown ESP Layout

3-1 Cumulative Mass Loading as a Function of Particle Size at ESP Inlet

3-2 Cumulative Weight Percent Less Than Indicated Size at ESP Inlet

3-3 Differential Mass Distribution at ESP Inlet

3-4 Differential Number Distribution at ESP Inlet

3-5 Cumulative Mass Loading as a Function of Particle Size at ESP Outlet

3-6 Cumulative Weight Percent Less Than Indicated Size at ESP Outlet

3-7 Differential Mass Distribution at ESP Outlet

3-8 Differential Number Distribution at ESP Outl,et

3-9 Fractional Efficiency Curve

3-10 Partlcie Size Distribution Based on Five-Stage Cyclones

3-11 Voltage-Current Curve for East Inlet $T-R$ Set. on May 11, 1983

3-12 Voltage-Current Curve for West Inlet $T-R$ Set on May 11, 1983

3-13 Voltage-Current Curve for East Outlet $T-R$ Set on May 11, 1983

3-14 Voltage-Current Curve for West Outlet $T-R$ Set on May 11, 1983

3-15 Voltage-Current Curve for East Inlet $T-R$ Set on May 13, 1303

3-16 Voltage-Current Curve for West Inlet $T-R$ Set on May 12, 1983

3-17 Voltage-Current Curve for East Outlet T-R Set on May 12, 1983

4-1 Resistivity Measurements Made with Ascending and Decoonding Temperalule and Predicted Resistivity as a Function of Temperature

4-2 Predicted Effect of $\mathrm{so}_{3}$ on Resistivity at an Electric Fleld Intensity of $4 \mathrm{kV} / \mathrm{cm}$

4-3 In Situ and Iaboratory Resistivity Measurements with $\mathrm{SO}_{3}$ and Predicted Resistivity for Various $\mathrm{SO}_{3}$ Levels 


\section{TABLES}

Table

Page

3-1 Sampling and Measurement Activities

3-2

3-2 Pxoximate and Ultimate Coal Analyses

3-2

3-3 Fly Ash Composition

$3-3$

3-4 Mass Train Data

$3-4$

3-5 In Situ Resistivity Measurements

$3-15$

3-6 Flue Gas $\mathrm{so}_{x}$ and $\mathrm{NH}_{3}$ Analyses

$3-16$

3-7 Five-stage Cyclone Data

$3-17$

4-1 Physical and Chemical Data for Outlet Hopper Sample

$4-2$

4-2 Effect of Sulfur Trioxide on Lab-Measured Resistivity

$4-4$ 
EXECUTIVE SUMMARY

The Big Brown Station of Texas Utilities Generating Company employs a combination of $\mathrm{NH}_{3}$ and $\mathrm{SO}_{3}$ injection to condition the fly ash from a relatively low-grade Texas lignite. Station personnel report that this dual conditioning system has been found to, be more effective than either $\mathrm{NH}_{3}$ or $\mathrm{SO}_{3}$ injection alone in improving the performance of the cold-side precipitators at Big Brown. The mechanisms by which the dual conditioning system works are not fully understood.

The field and laboratory studies described in this report provide additional information concerning the combined $\mathrm{NH}_{3}-\mathrm{SO}_{3}$ conditioning process. This work provides some new understanding of the mechanisms, but it stops short of a definitive analysis. This is largely because field studies could not be done with one or both of the conditioning agents turned off. Nevertheless, laboratory studies have made it possible to infer some additional information concerning the role of $\mathrm{SO}_{3}$ and $\mathrm{NH}_{3}$ conditioning at Big Brown.

The precipitator tested in this study (ESP 2-1) services one-fourth of the flue gas generated by the Unit 2 boiler at Big Brown. The Unit 2 boiler is a combustion Engineering pulverized-coal fired unit with a rated generating capacity of $575 \mathrm{MW}$. Both Units 1 and 2 fire a wilcox group Texas lignite that is mined on site at the plant. Lignite samples taken from one of the Unit 2 feeders during the testing showed an average heating value of $7000 \mathrm{Btu} / \mathrm{lb}$ and an average ash content of 178 on an as-received basis. The daily samples also showed considerable variability in the lignite composition.

Laboratory studies indicate that the combined $\mathrm{SO}_{3}-\mathrm{NH}_{3}$ conditioning results in a surface film on the ash particles which reduces their resistivity by about one order of magnitude. This was found to be roughly comparable to the effect produced by equilibrating the ash with the level of $\mathrm{SO}_{3}$ present in the gas phase at the ESP inlet. The ash containing the surface film (i.e., the as-received ash) was also found to be more receptive to $\mathrm{SO}_{3}$ conditioning than the same ash with the surface film removed by thermally annealing the ash at $450^{\circ} \mathrm{C}$ overnight. This suggests that the $\mathrm{NH}_{3}$ serves to make the ash more receptive to $\mathrm{so}_{3}$ conditioning. It is speculated 
that this may be due to a reduction in the vapor pressure of the surface film caused by the dissolution of the ammonium compounds in the excess acid on the particle surfaces. Additional work would be required to confirm this conjecture.

The soluble sulfate content of the ash was greater than expected for complete adsorption of the total amount of $\mathrm{so}_{3}$ present in the flue gas 15 ppm from the coal and 9 ppm from the injection system). This observation was attributed to additional uptake of $\mathrm{SO}_{3}$ by the ash as it resided in the mass train thimble and was exposed to flue gas being pumped through it. Abcut 768 of the injected $\mathrm{NH}_{3}$ was found on the ash surface as $\mathrm{NH}_{4}{ }^{+}$, probably in either ammonium sulfate or ammonium bisulfate dissolved in the excess acid condensed on the ash surface.

In terms of electrical operation and collection efficiency, the performance of the Big Brown ESP was quite good, considering its small size (SCA $\left.=166 \mathrm{ft}^{2} / \mathrm{kacfm}\right) \cdot \mathrm{The}$ average mass efficiency determined by EPA Method 17 was about 98.58 with a mean inlet grain lcading of $6.64 \mathrm{gr} /$ dscf. The fractional efficiency curve for ESP 2-1, which was derived frcm cascade impactor measurements made at the inlet and outlet of the ESP, showed a minimum efficiency at about $0.8 \mu \mathrm{m}$. Above 1 um the curve was qualitatively consistent with theory. All $T-R$ sets tested had well-behaved voltagecurrent curves, and the electrical operating conditions of the ESP were apparently not limited by the resistivity of the ash. The actual resistivity of the conditioned ash is estimated to be on the order of $10^{10} \mathrm{ohm} \mathrm{cm}$. This value was measured in the laboratory after equilibration of the as-received ash with the level of so 3 present at the ESP inlet. This value is lower than the in situ resistivity data, which are inconsistent with the electrical nperating conditions of the ESP. Using a resistivity of $1 \times 10^{10} \mathrm{ohm} \mathrm{cm}$ alonq with troical nrin-ineal sorreotion faotors; lle theoretically predicted collection efficiency for the Big Brown ESP is almost exactly equal to the measured value. The excellent agreement between theory and measurement may be partly fortuitous, but it does indicate that there were no significant mechanical or electrical problems with the ESP.

The field test results described here tend to confirm the assertions of plant personnel that the combined $\mathrm{NH}_{3}-\mathrm{SO}_{3}$ conditioninq process may he a useful means of maintaining acceptable performance levels in a cold-side ESP. Additional work is still required, however, to determine whether this process can be more effective than using either $\mathrm{SO}_{3}$ or $\mathrm{NH}_{3}$ alone. A complete understanding of the mechanisms involved in $\mathrm{NH}_{3}-\mathrm{SO}_{3}$ conditioning would also require additional work. In particular, field measurements are needed with and without either agent and both agents in use. The effect of $\mathrm{NH}_{3}-\mathrm{SO}_{3}$ conditioning on rapping reentrainment also needs to be assessed. 
Section 1

INTRODUCTION

This report deals with the second jointly-sponscred field test funded by the Department of Energy (DOE) and the Electric Power Research Institute (EPRI) under DOE Contract No. DE-AC18-80FC10225 and EPRI Contract No. RP724-2. The second jointly-sponsored field test was conducted at the Big Brown station of the Texas Utilities Generating Company during the period of May 9-13, 1983. This report summarizes the results of the field and laboratcry measurements. The field test conducted at the Big Brown station was designed to satisfy the objectives of both the DOE and EPRI projects.

The primary objectives of DOE were to evaluate the performance of the precipitator and to obtain data on the concentration, composition, and size distribution of the fly ash, the flue gas composition, and the overall and fractional collection efficiencies of the precipitator, and to collect coal and size-fractiunated ash for furthex characterization. EPRI's interest in the program was primarily concerned with developing data that could be used to increase the capability for predicting the resistivity of $\mathrm{fly}$ ashes of varying compositions as a function of temperature and $\mathrm{SO}_{3}$ concentration in the flue gas. EPRI is also interested in the combined effects of $\mathrm{NH}_{3}$ and $\mathrm{SO}_{3}$ and their reaction products on ash resistivity, so the $\mathrm{Big}$ Brown Station was of particular interest since it employed a rather unusual conditioning technique utilizing both of these chemicals.

It is the ultimate objective of DOE to use the data developed from this field test, along with data from cther similar tests, to assess the applicability of different types of control devices in controlling particulate emissions from the combustion of low-rank western coals in utility boilers. It is also the intent of DOE to use these data in assessing the ability of the pilot-scale combustion facility at Grand Forks to reproduce the characteristics of the fly ash and flue gas produced by fullscale utility boilers. 
Section 2

SITE SELECTION AND DESCRIPTION

The Big Brown Station was selected as the site of the second jointly-sponsored field test because it burns a low-grade Texas lignite which is of interest to DOE, and it uses a flue gas conditioning system of interest to EPRI. The site was specifically of interest to EPRI because of the opportunity to conduct testing with the combined $\mathrm{SO}_{3}$ and $\mathrm{NH}_{3}$ conditioning system mentioned previously.

The Big Brown Station is a mine-mouth facility located in Fairfield, Texas, about 80 miles southeast of Dallas. The plant consists of two pc-fired units. The boilers are Combustion Engineering natural circulation, balanced draft units, with a rated generating capacity of $575 \mathrm{MW}$ each. The furnaces are tangentially fired. Both units fire a Wilcox group Texas lignite that is mined on site at the plant. The composition of the lignite is given in section 3 .

The ESP layout at Big Brown is illustrated in Figure 2-1. The flue gas stxeam exiting the boiler passes through two air preheaters and then through four separate casings of a Research-Cottrell cold-side, double-Chevron ESP. The flue gas enters the ESP at a nominal temperature of $370^{\circ} \mathrm{F}$. One-fourth of the Unit 2 ESP was tested (ESP 2-1). The 2-1 ESP has two chambers with two electrical fields per chamber, as did all of the other precipitators on this unit. The ESP uses a weighted-wire discharge electrode design. The plate spacing is 9 in. All fields are equipped with standard $0.109=i n$, wire Aischarge electrodes. The collection plates are $30 \mathrm{ft}$ in height and $9 \mathrm{ft}$ in depth.

As mentioned previously, both $\mathrm{SO}_{3}$ and $\mathrm{NH}_{3}$ are injected into the flue gas. The so 3 is injected ahead of the air preheater at a rate of 9 ppm. The $\mathrm{NH}_{3}$ is injected between the alr preheater and the ESP at a rate of $5 \mathrm{ppm}$. These injection rates were confirmed by flue gas analyses discussed later. 


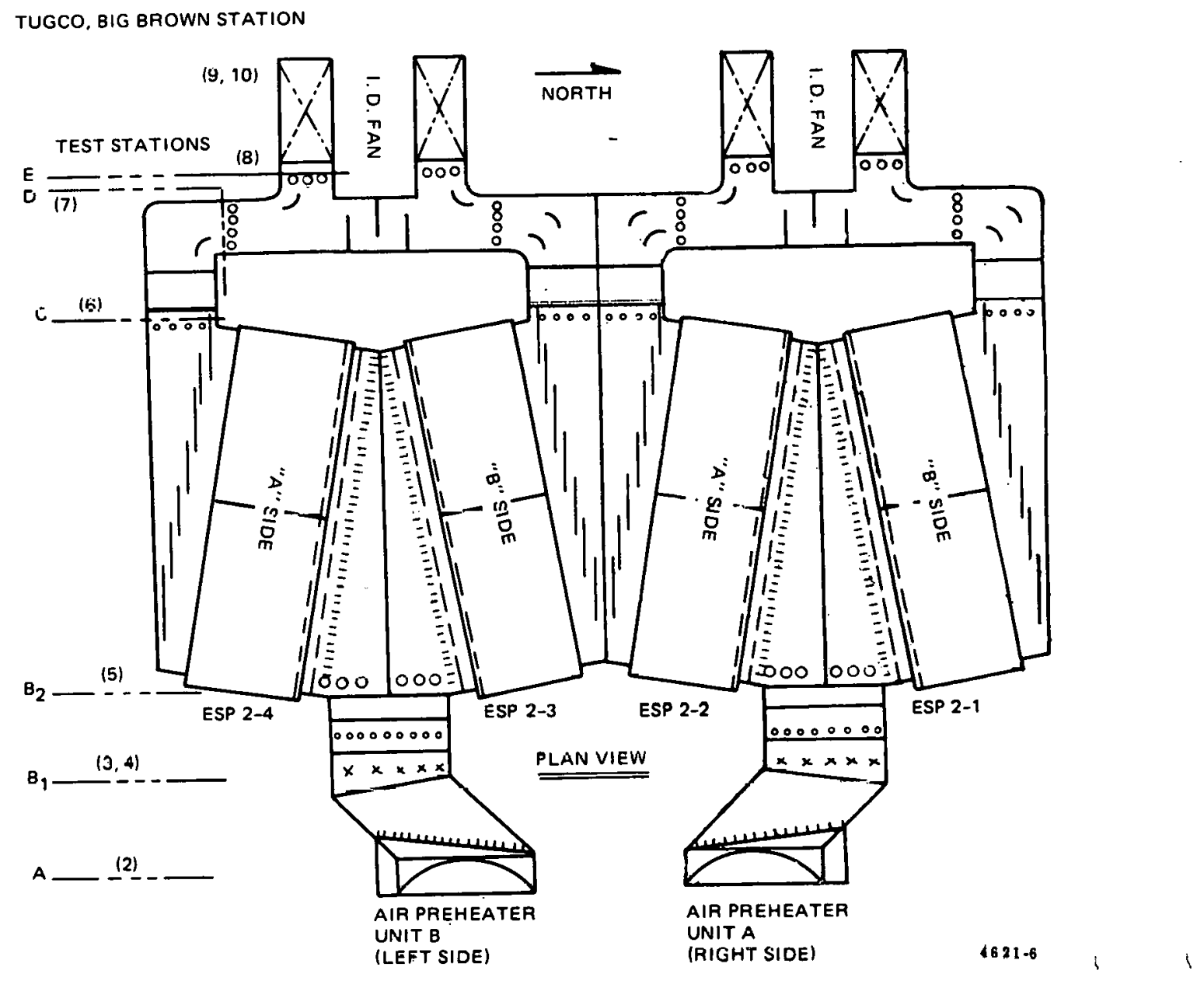

Figure 2-1 Big Brown ESP Layout 
Section 3

FIELD TEST RESULTS

SAMPLING AND MEASUREMENT ACTIVITIES

A summary of the sampling and measurement activities performed during the Big Brown test is given in Table 3-1. EPA Method 17 (1) mass trains were used to determine the inlet and outlet mass loadings and the overall efficiency of the ESP. Calibrated cascade impactors were employed to quantify the inlet and outlet particle size distributions and the fractional efficiency of the ESP. The electrical resistivity of the fly ash was measured in situ using a point-plane probe. Relatively large samples of the fly ash were collected in a five-stage cyclone assembly for subsequent laboratory analyses at Grand Forks. The flue gas was sampled and analyzed for $\mathrm{CO}_{2}$ using a Fyrite analyzer, for $\mathrm{O}_{2}$ using a Teledyne portable $\mathrm{O}_{2}$ meter, for $\mathrm{H}_{2} \mathrm{O}$ by adsorption in Drierite tubes, and for $\mathrm{SO}_{x}$ using the Cheney-Homolya (2 $)$ sampling system. Twenty-five barrels of coal were collected from the Unit 2 coal feeder discharge. This coal was then shipped to Grand Forks for use in the pilotscale combustor. More detailed descriptions of the sampling and analytical techniques and results are given later in this report.

CHARACTERIZATION OF COAL AND FLY ASH

Samples of the coal taken at the Unit 2 feeder discharge were submitted to Commercial Testing and Engineering Company of Birmingham for proximate and ultimate analyses. The results are given in Table 3-2. The very high ash content and low heating value make this lignite a relatively low-grade fuel. The analyses also indicate that the fuel composition varied considerably during the test period.

Fly ash samples collected in inlet mass train thimbles were analyzed by atomic absorption spectrometry using a digested sample which had been Ignited at $750^{\circ} \mathrm{C}$. The results are given in Table 3-3. Important features of these ash analyses are the low alkali metal content and high alkaline earth content which contribute to the high resistivity of this ash without $\mathrm{sO}_{3}$. The loss on ignition was reasonably low.

The $\mathrm{NH}_{4}{ }^{+}$content of the ash indicates that most of the injected $\mathrm{NH}_{3}$ was adsorbed on the ash. Adsorption of 5 ppr of $\mathrm{NH}_{3}$ onto $\mathrm{fly}_{\mathrm{Y}}$ ash particles having a mass loading of 
Table 3-1

SAMPLING AND MEASUREMENT ACTIVITIES

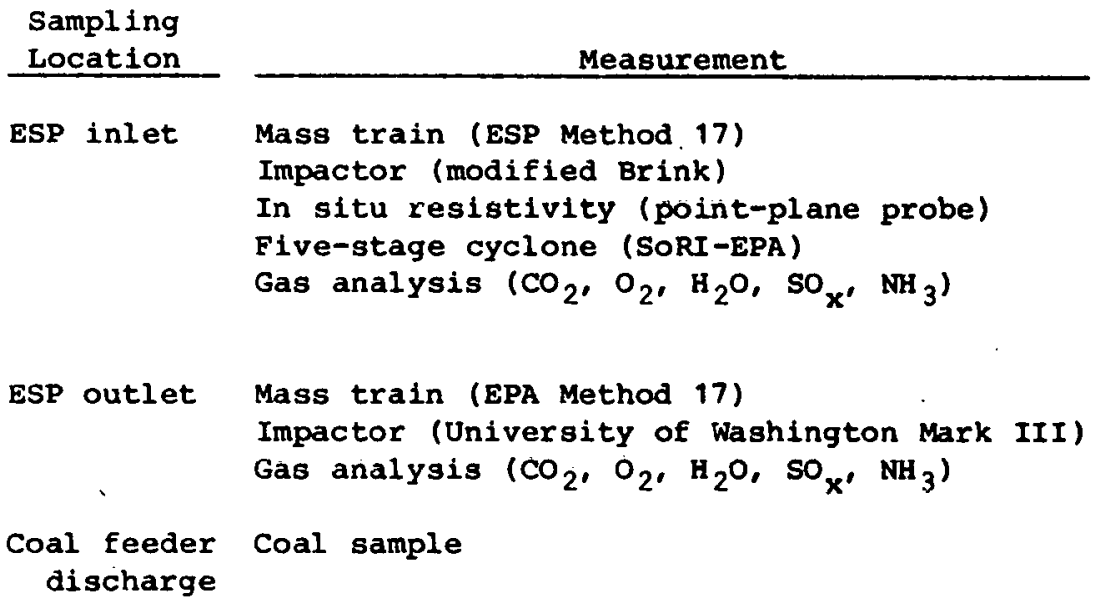

\begin{tabular}{|c|c|c|c|c|c|}
\hline 1 & 2 & 3 & 4 & 5 & 6 \\
\hline $\mathbf{T}$ & $\mathbf{s}$ & + & & & $\mathbf{P}$ \\
\hline $\mathbf{R}$ & $\boldsymbol{E}$ & & + & + & $\mathbf{A}$ \\
\hline A & $\mathbf{T}$ & + & + & + & C \\
\hline V & & + & + & + & $\mathbf{K}$ \\
\hline $\mathbf{E}$ & $\mathrm{U}$ & + & + & + & \\
\hline I & $\mathbf{P}$ & & & & $\mathbf{A}$ \\
\hline & $F$ & + & & & $\begin{array}{l}\mathbf{N} \\
0\end{array}$ \\
\hline & $\mathbf{Q}$ & & + & + & \\
\hline & U & + & + & + & $\mathbf{T}$ \\
\hline & I & & & & $\mathbf{R}$ \\
\hline & $\mathbf{P}$ & + & + & + & A \\
\hline & $\mathbf{M}$ & & & & $\mathbf{v}$ \\
\hline & $\mathbf{E}$ & & & & $\mathbf{E}$ \\
\hline & $\mathbf{N}$ & & & & L \\
\hline
\end{tabular}

Table 3-2

PROXIMATE AND ULTIMATE COAL ANALYSES

(as-received basis) $^{a}$

\begin{tabular}{|c|c|c|c|c|}
\hline \multicolumn{5}{|c|}{ Proximate } \\
\hline 8 & Mo1sture & 21.07 & 29.37 & 31.51 \\
\hline 8 & Ash & 14.41 & 23.05 & 12.91 \\
\hline 8 & Volatile & 42.21 & 22.42 & 50.45 \\
\hline 8 & Fixed carbon & $22 \cdot 31$ & 25.16 & 5.13 \\
\hline & $t u / 1 b$ & 8,671 & 5,978 & 6,153 \\
\hline \& & Sulfur & 0.91 & 0.85 & 0.73 \\
\hline \multicolumn{5}{|c|}{ Ultimate } \\
\hline 8 & Molsture & 21.07 & 29.37 & 31.51 \\
\hline 8 & Carbon & 51.49 & 35.22 & 39.50 \\
\hline 8 & Iyitrougein & 2.81 & 2.30 & 2.68 \\
\hline 8 & Nitrogen & 1.12 & 0.71 & 0.64 \\
\hline & Chlorine & 0.06 & 0.05 & 0.0 .0 \\
\hline 8 & Sulfur & 0.91 & 0.85 & 0.73 \\
\hline 8 & Ash & 14.41 & 23.05 & 12.91 \\
\hline 8 & oxygen ${ }^{b}$ & 8.13 & 8.36 & 11.98 \\
\hline
\end{tabular}

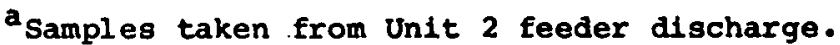

boxygen determined by difference.
} 
Table 3-3

FLY ASH COMPOSITION ${ }^{a}$

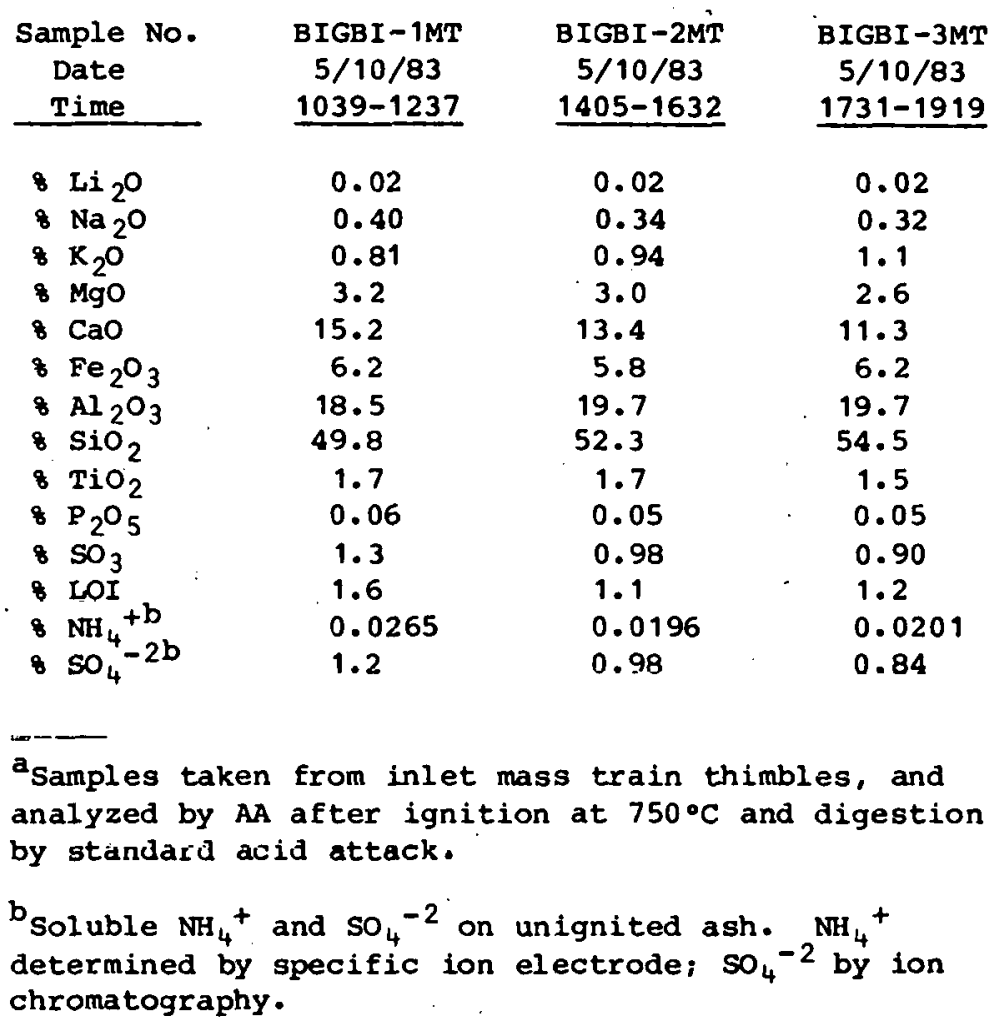

$6.64 \mathrm{gr} / \mathrm{dscf}$ (the average measured mass loading) would be expected to produce an $\mathrm{NH}_{4}{ }^{+}$concentration of 0.0298 by weight, assuming complete adsorption. The mean measured $\mathrm{NH}_{4}{ }^{+}$concentration $(0.0228)$ represents 768 of this value.

The measured $\mathrm{SO}_{4}{ }^{-2}$ content of the ash is higher than expected for complete adsorption of $14 \mathrm{ppm}$ of $\mathrm{SO}_{3}$. Assuming the same mass loading used above, this should produce a sulfate concentration of about 0.48 . However, the measured values ranged from 0.84 to 1.28 . The most likely explanation appears to be that the ash adsorbed additional $\mathrm{So}_{3}$ while it resided in the mass train thimble filter. An ash sample taken from one of the outlet ESP hoppers also had a relatively high $\mathrm{SO}_{4}{ }^{-2} \mathrm{content}$ as alscussed in the section on the laboratory characterization of the ash.

METHOD 17 RESULTS AND MASS EFEICIENCY

Mass loadings were measured at the $A$ side iniet to ESPs 2-1 and 2-2 and at the outlet of ESP 2-1 by EPA Method 17 (1). Each sampling location was traversed with 
mass trains equipped with in-stack filters. Isokinetic sampling was approximated as closely as possible at each sampling point. The measured mass loadings are given in Table 3-4. During this testing the boiler load was maintained fairly constant in the range of 560 to $580 \mathrm{MW}$, with excess air in the range of 13 to 198. The stack opacity recorded by the plant transmissometer was between 26 and 328 .

Table 3-4

MASS TRAIN DATA

\begin{tabular}{|c|c|c|c|c|c|c|c|c|c|}
\hline $\begin{array}{l}\text { Run } \\
\text { No. }\end{array}$ & $\begin{array}{l}\text { Load } \\
\text { (MW) } \\
\end{array}$ & $\begin{array}{l}\text { Temp. } \\
(\circ \mathrm{F})\end{array}$ & $\begin{array}{c}\text { SCA } \\
\left(\mathrm{Et}{ }^{2} /\right. \\
\text { kacfm) }\end{array}$ & $\begin{array}{c}\text { Inlet } \\
\text { Ioading } \\
\text { (gr/dscf) }\end{array}$ & $\begin{array}{c}\text { Inlet } \\
\text { Percent } \\
\text { Isokinetic } \\
\end{array}$ & $\begin{array}{c}\text { Outlet } \\
\text { Ioading } \\
\text { (gr/dscf) } \\
\end{array}$ & $\begin{array}{c}\text { Outlet } \\
\text { Percent } \\
\text { Isokinetic } \\
\end{array}$ & $\begin{array}{l}\text { Efficiency } \\
(8) \\
\end{array}$ & $\begin{array}{l}\text { Opacity } \\
(8) \\
\end{array}$ \\
\hline 1 & 580 & 380 & 171 & 6.22 & 105.7 & 0.111 & 97 & 98.22 & 26.4 \\
\hline 2 & 568 & 385 & 163 & 6.37 & 109.8 & 0.0783 & 99.4 & 98.77 & 27.5 \\
\hline 3 & 566 & 385 & 165 & 7.32 & 109.9 & 0.120 & 99.1 & 98.36 & 31.8 \\
\hline
\end{tabular}

During the test period the average flue gas flow rate through the $A$ slde of ESP 2-1 was $1.3 \times 10^{6} \mathrm{acfm}$ at $370^{\circ} \mathrm{F}$, resulting in an operating SCA of $166 \mathrm{ft}^{2} / 1000$ acfm, almost exactly equal to the design value. The average inlet and outlet mass loadings were 6.64 and $0.103 \mathrm{gr} / \mathrm{dscf}$, yielding an average efficiency of 98.458 .

PARTICLE SIZE DISTRIBUTIONS AND FRACTIONAL EFFICIENCY

The inlet and outlet particle size distributions were determined from in-stack cascade impactor sampling using modified Brink impactors at the inlet and University of Washington Mark III impactors at the outlet. Seven real impactor runs and one blank run were performed in separate sampling ports at the inlet, while six complete traverses of duct area were performed at the outlet with two blanks. Glass fiber substrates were used in the impactors. The blank runs did not reveal any appreclable substrate interference problems.

Figures 3-1 through 3-8 show the inlet and outlet particle size distributions determined from the impactor sampling. Figures 3-1 and 3-5 show the cumulative mass concentration of all particles smaller than the stated diameter, which was obtained by summing the masses collected on each impaction stage and dividing by the volume of flue gas sampled. In order to calculate the mass median diameters, the curves were extrapolated to the total mass concentration at an assumed maximum particle 


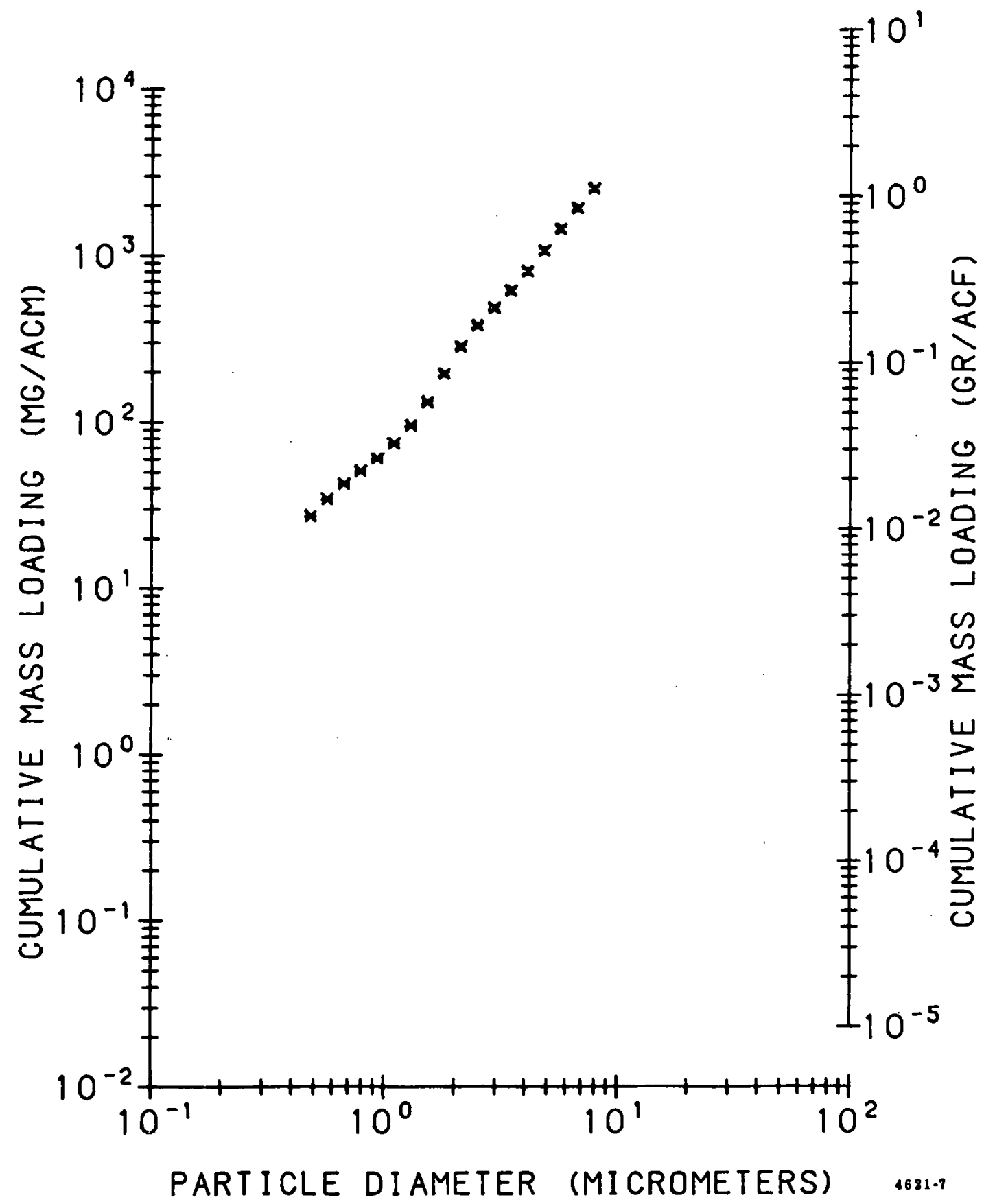

Figure 3-1 Cumulative Mass Loading as a Function of Particle Size at ESP Inlet 


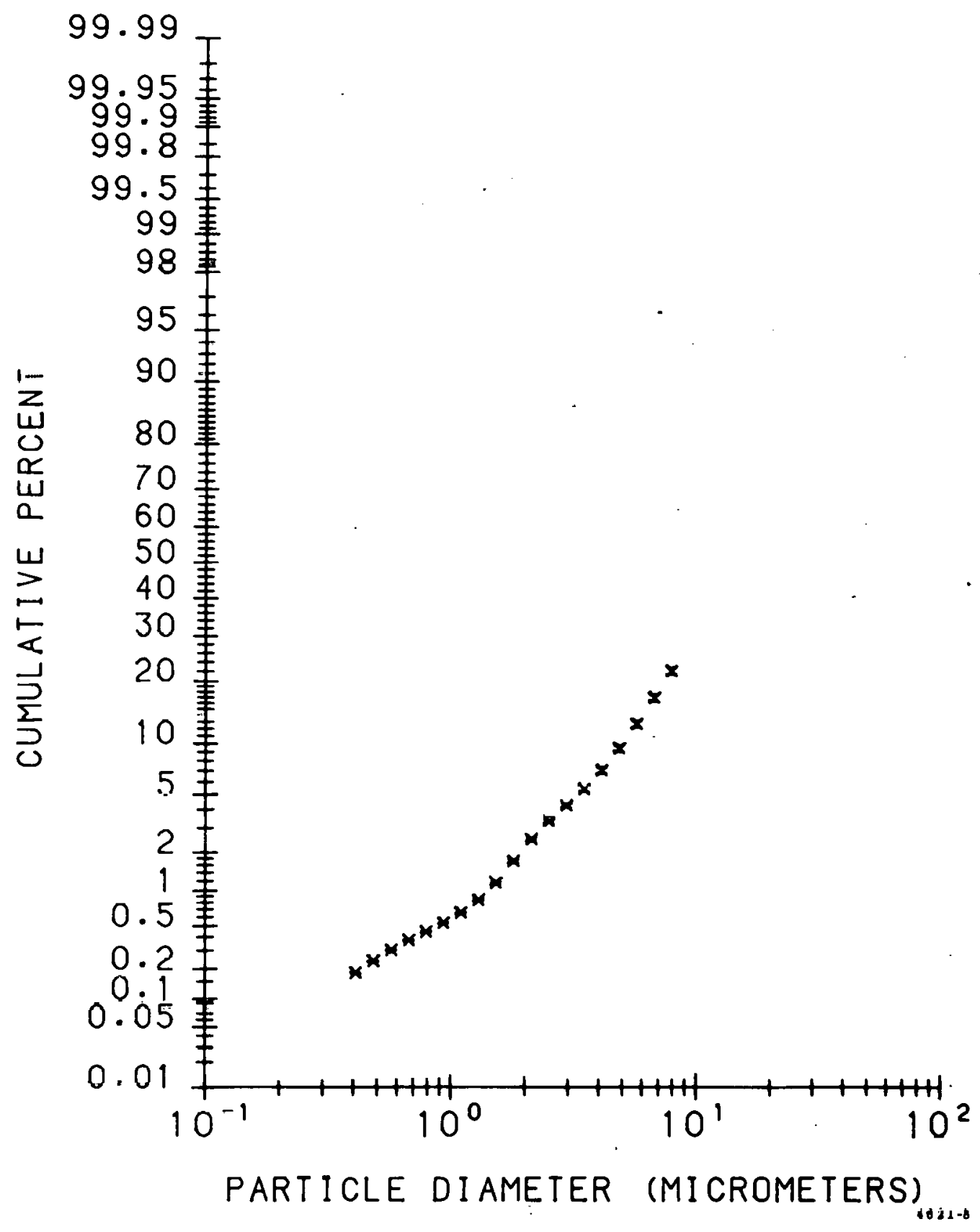

Figure 3-2 Cumulative Weight Percent Less Than Indicated Size at ESP Inlet 


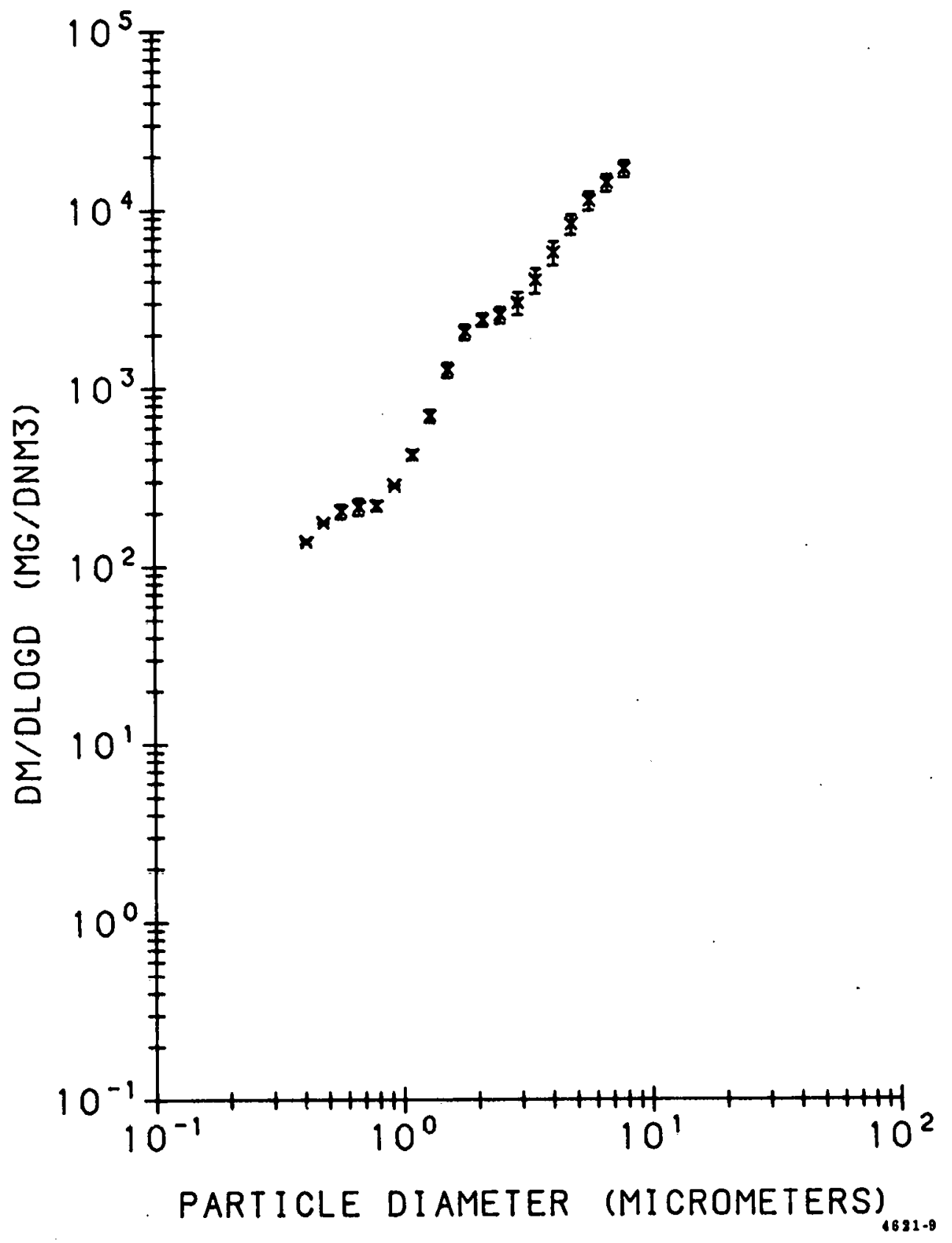

Figure 3-3 Differential Mass Distribution at ESP Inlet 


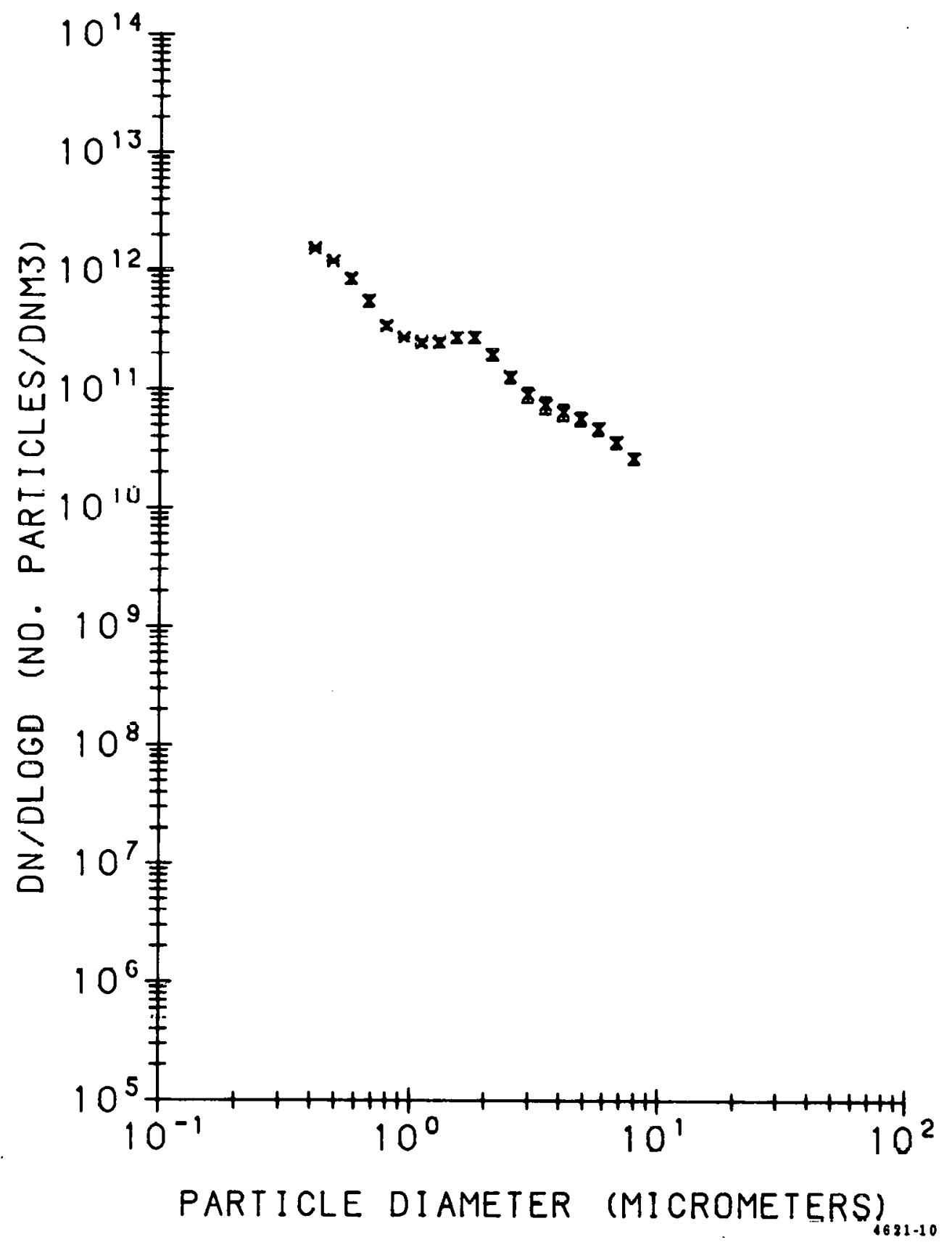

Figure 3-4 Differential Number Distribution at ESP Inlet 


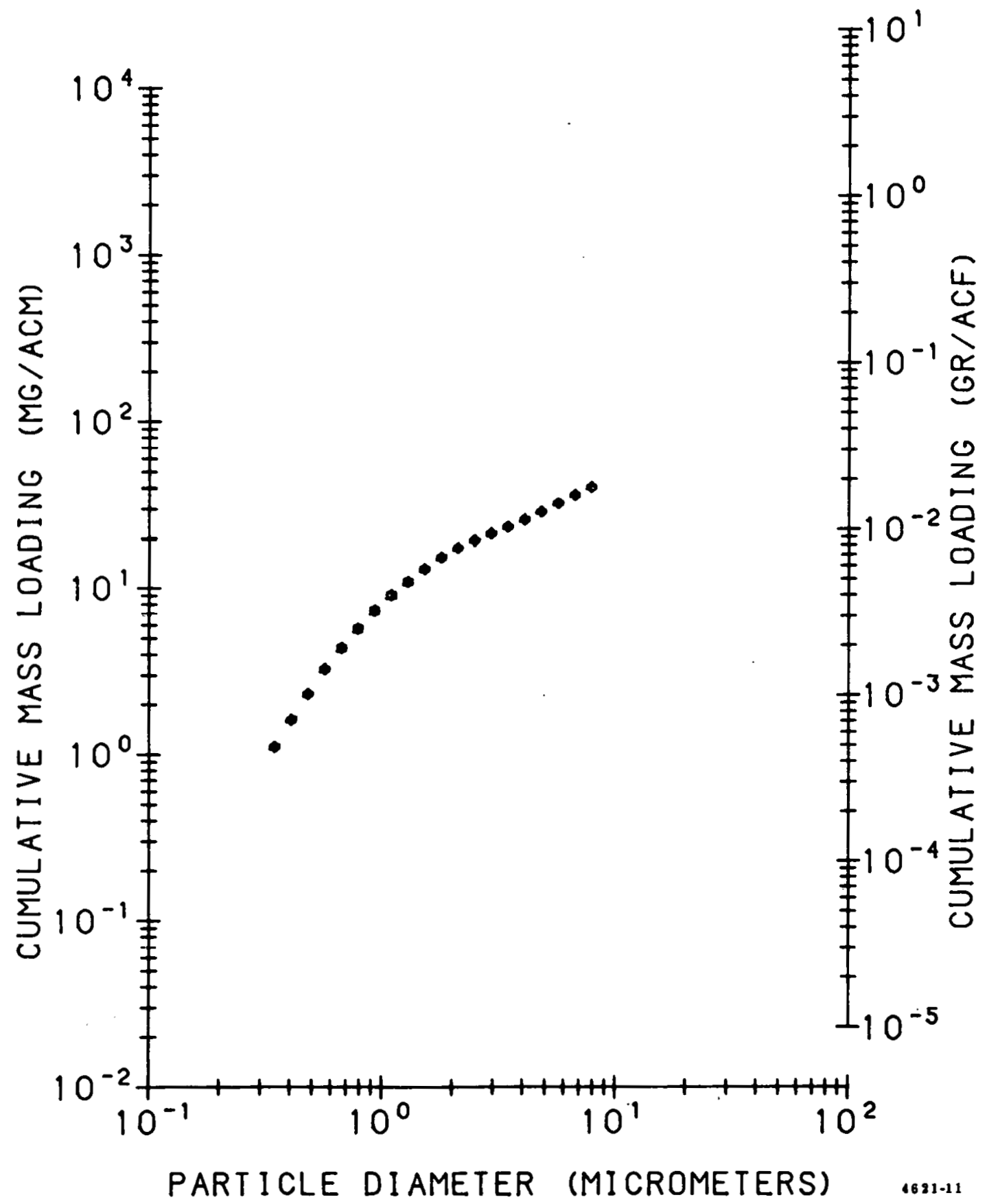

Figure 3-5 Cumulative Mass Loading as a Function of Particle Size at ESP Outlet 


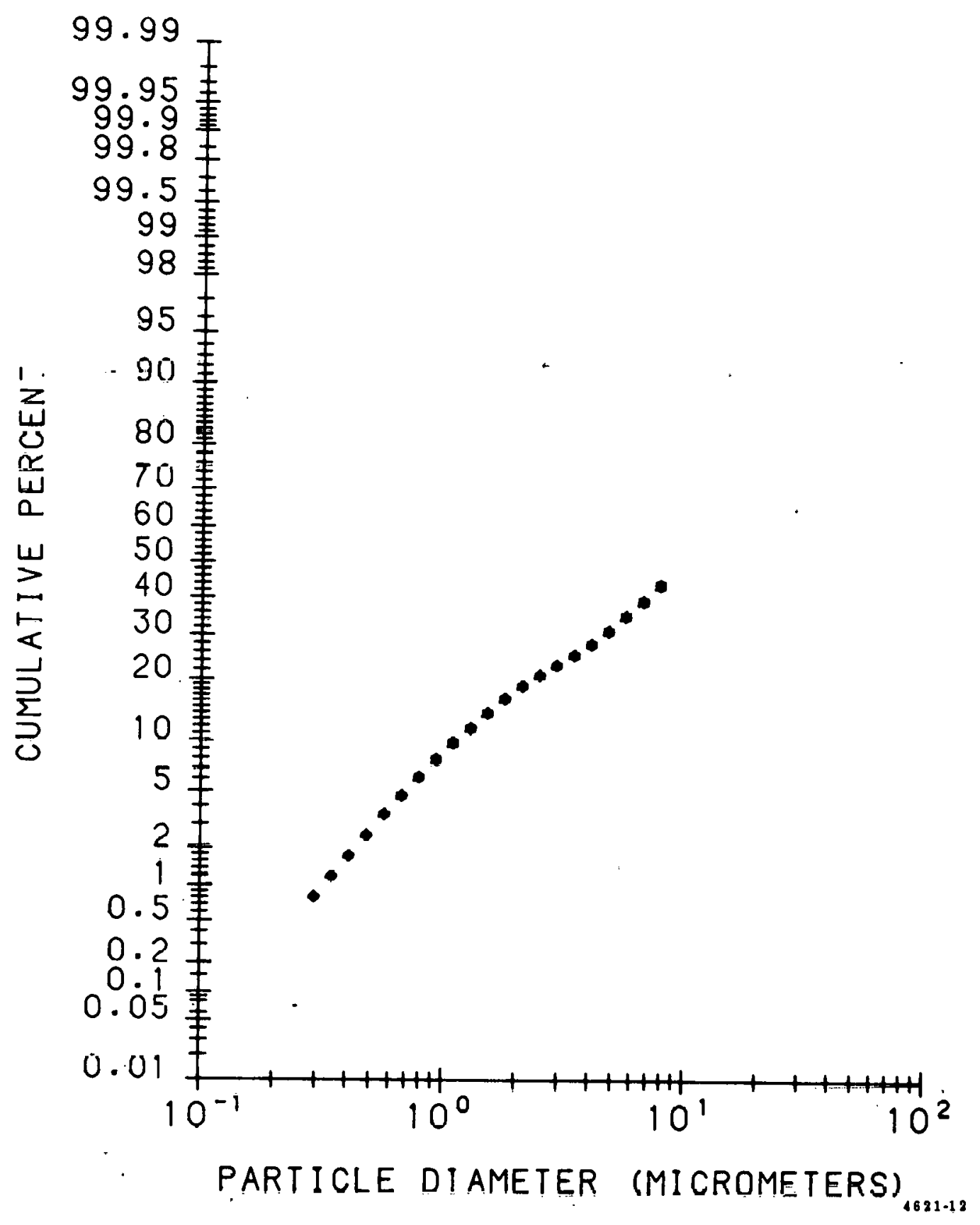

Figure 3-6 Cumulative Weight Percent Less Than Indicated Size at FSP Qut/et 


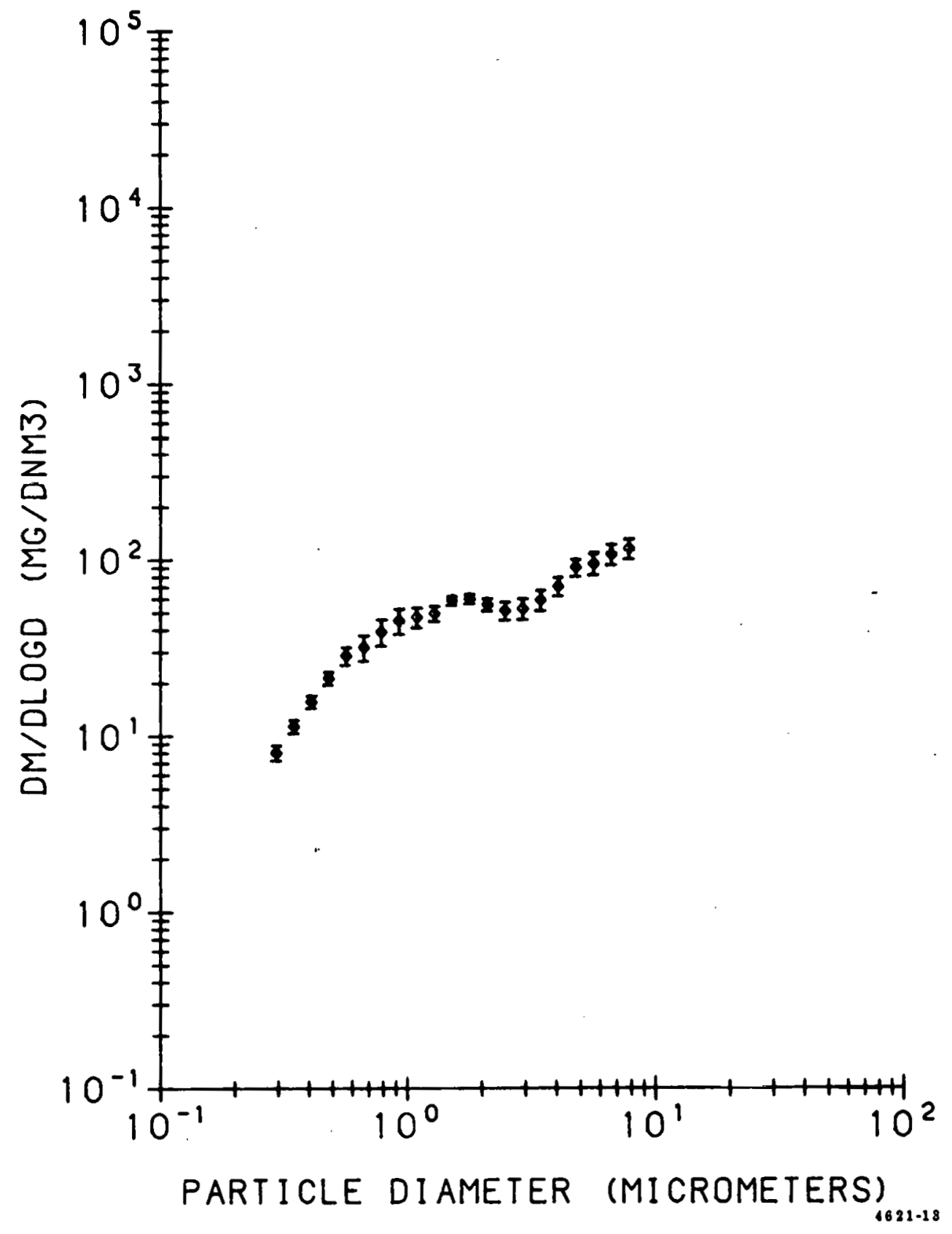

Figure 3-7 Differential Mass Distribution at ESP Outlet 


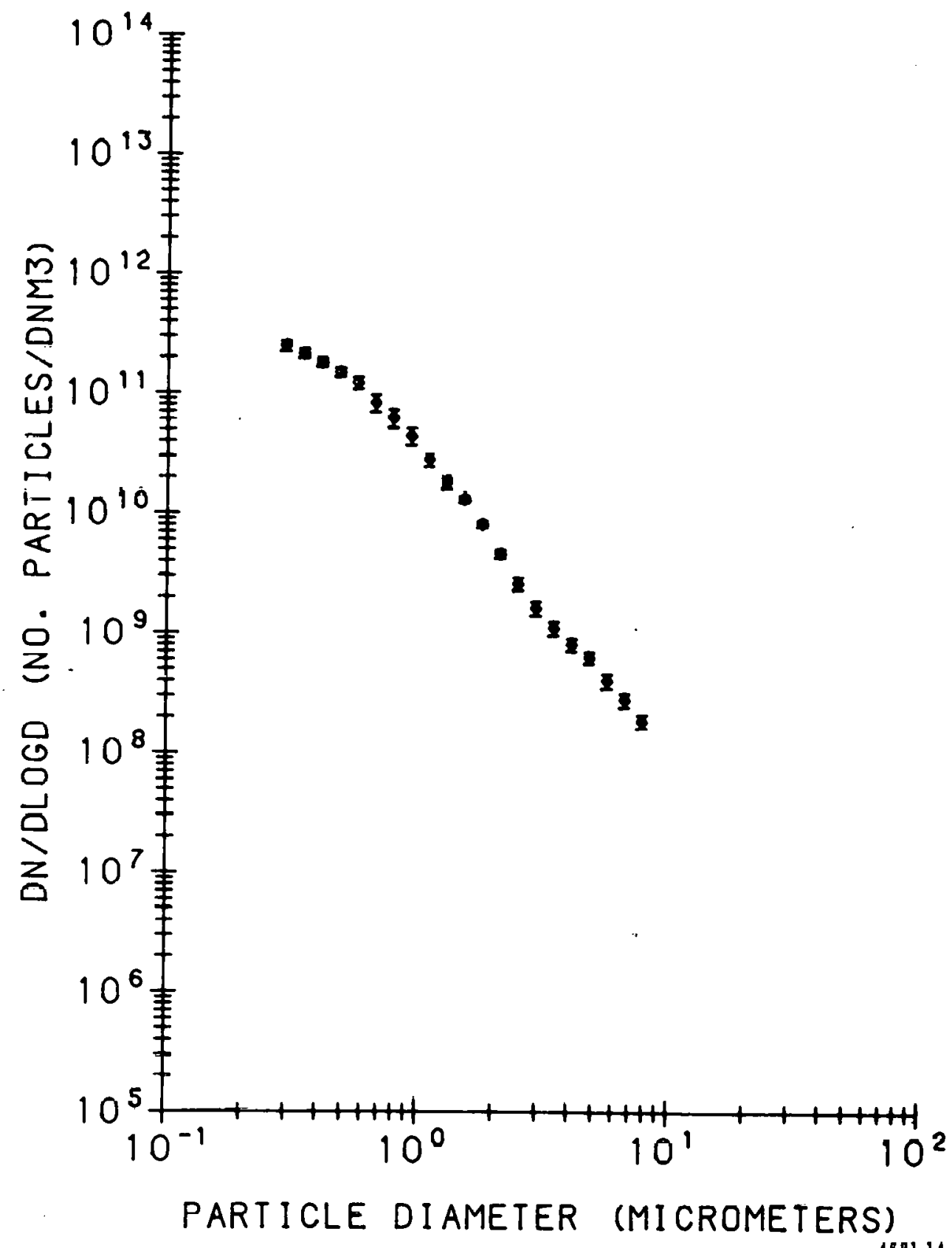

Figure 3-8 Differential Number Distribution at ESP Outlet 
diameter of $100 \mathrm{~mm}$ at the inlet and $20 \mathrm{~km}$ at the outlet. The mass median diameters of the inlet and cutlet size distributions, based on the impactor data, are approximately $14 \mathrm{~mm}$ and $9 \mathrm{~mm}$, respectively.

The curves shown ir. Figures 3-1 to 3-8 were obtained by averaging the spline fits (3) to a number of impactor runs; the points do not represent the raw impactor data, but rather the interpolated points generated by the spline fit.

Figures 3-2 and 3-6 show the inlet and outlet distributions on the basis of cumulative percent smaller than the stated sizes. Figures 3-3 and 3-7 give the differential mass distributions and Figures 3-4 and 3-8 give the differential number distributions, assuming a particle density of $2.4 \mathrm{~g} / \mathrm{cm}^{3}$.

The fractional efficiency curve derived fxom the inlet and outlet impactor measurements is shown in Figure 3-9. This apparently shows a minimum in the collection efficiency at just below $1 \mathrm{\mu m}$. The curve appears to be qualitatively conslstent with theoretically predicted fractional efficiency curves in the range of 1 to $10 \mathrm{\mu m}$. The fractional efficiencies are also consistent with the measured overall efficiency if one considers that half of the mass is contained in particles larger than $14 \mathrm{~m}$. The cumulative efficiency for collection of sub-5-um particles was 978 .

IN SITU RESISTIVITY AND $\mathrm{SO}_{\mathbf{x}}$ AND $\mathrm{NH}_{3}$ MEASUREMENTS The SoRI in situ point-plane probe was used to measure the electrical resistivity of the ash by the sparkover method. This procedure is described in detail in EPA Report EPA 600/8-80-025 (4) . All of these measurements were made at the inlet of the A side of ESP 2-1. The results are given in Table 3-5. The average resistivity determincd by the sparknver technique was $1.6 \times 10^{11} \mathrm{ohm} \mathrm{cm}$, with considerable scatter in the data.

Although the measured resistivity varied considerably, the $\mathrm{so}_{3}$ and $\mathrm{NH}_{3}$ measurements did not show corresponding variations. Netther did the electrical operating conditions of the ESP. Therefore, it appears that the in situ resistivity measurements are inconsistent with the other data. Given this problem and the large amount of scatter evident in the in situ resistivity data, the reliability of these data must be questioned. This problem is discussed more completely and compared to laboratory results in section 4 . 


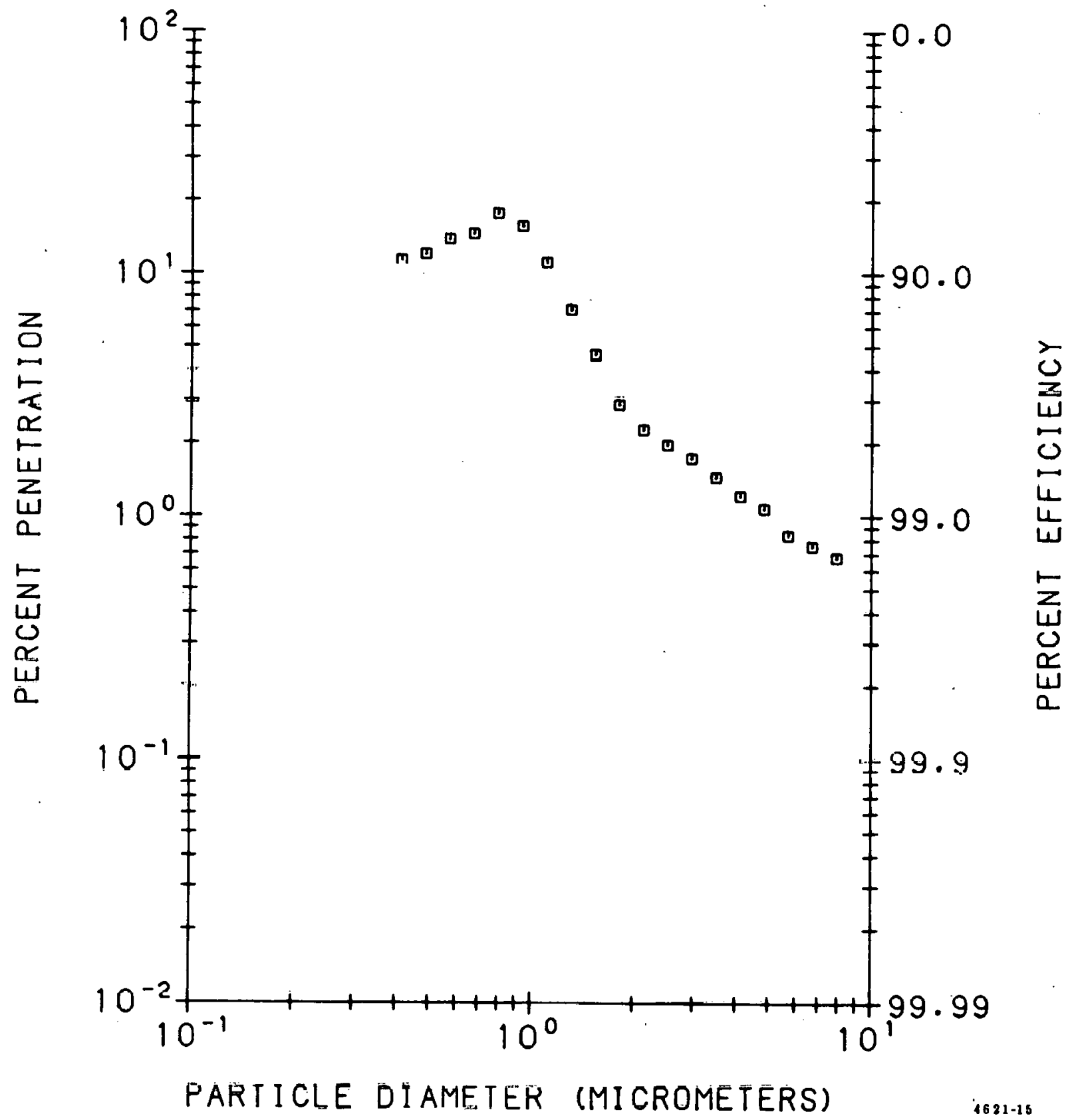

Figure 3-9 Fractional Efficiency Curve

c. 
Table 3-5

IN SITU RESISTIVITY MEASUREMENTS

\begin{tabular}{|c|c|c|c|}
\hline Date & $\begin{array}{l}\text { Run } \\
\text { No. }\end{array}$ & $\begin{array}{c}\text { Flue Gas Temp } \\
\left({ }^{\circ} F\right)\end{array}$ & $\begin{array}{l}\text { Resistivity } \\
(\mathrm{ohm} \mathrm{cm})\end{array}$ \\
\hline \multirow[t]{3}{*}{$5 / 10$} & 1 & 320 & $2.3 \times 10^{10}$ \\
\hline & 2 & 343 & $4.5 \times 10^{11}$ \\
\hline & 3 & 367 & $2.5 \times 10^{11}$ \\
\hline \multirow[t]{2}{*}{$5 / 11$} & 4 & 343 & $1.1 \times 10^{11}$ \\
\hline & 5 & 341 & $3.8 \times 10^{11}$ \\
\hline \multirow[t]{3}{*}{$5 / 12$} & 6 & 351 & $5.1 \times 10^{10}$ \\
\hline & 7 & 348 & $2.1 \times 10^{10}$ \\
\hline & 8 & 348 & $3.1 \times 10^{10}$ \\
\hline & verage & 345 & $1.6 \times 10^{11}$ \\
\hline
\end{tabular}

So $_{x}$ samples were collected ahead of the air preheater and downstream of the Wahlco $\mathrm{SO}_{3}$ injection system using the regular Cheney-Homolya sampling system (2). For $\mathrm{SO}_{\mathbf{x}}$ and $\mathrm{NH}_{3}$ sampling at the ESP inlet and outlet locations, the probe and quartz filter temperature was reduced from $\sim 550^{\circ} \mathrm{F}$ to the prevailing flue gas temperature. This modification of the sampling procedure was necessary to prevent thermal decomposition of the ammonium sulfate particulate assumed to be present in the flue gas at these locations. The system was further modified for $\mathrm{NH}_{3}$ sampling by removing the condenser and substituting one of the two Greenburg-Smith bubblers for a Greenburg-Smith impinger. A dilute $\mathrm{H}_{2} \mathrm{SO}_{4}$ solution $(0.02 \mathrm{~N})$ was used as the collection medium for all $\mathrm{NH}_{3}$ samples.

So samplea were analyzed by a $\mathrm{Ba}\left(\mathrm{ClO}_{4}\right)_{2}$ titration with Thorin indicator; $\mathrm{NH}_{3}$ samples with a specific ion electrode. The results are given in Table 3-6. The data indicate that about $5 \mathrm{ppm}$ of natural $\mathrm{H}_{2} \mathrm{SO}_{4}\left(\mathrm{SO}_{3}\right)$ was present in the flue gas ahead of the air preheater. Downstream from the $\mathrm{SO}_{3}$ injection probes about $14 \mathrm{ppm}$ of $\mathrm{H}_{2} \mathrm{SO}_{4}$ was found. Therefore, it appears that approximately 9 ppm of $\mathrm{H}_{2} \mathrm{SO}_{4}$ was added to the flue gas by the injection system.

The absence of any significant concentrations of $\mathrm{H}_{2} \mathrm{SO}_{4}\left(\mathrm{SO}_{3}\right)$ at the EGP inlct $(<0.5 \mathrm{ppm})$ is presumably due to adsorption on fly ash and reaction with $\mathrm{NH}_{3}$. If the theoretical $\mathrm{NH}_{3}$ injection rate of $5 \mathrm{ppm}$ is correct, $2.5 \mathrm{ppm}$ of $\mathrm{H}_{2} \mathrm{SO}_{4}$ would have been consumed in the formation of ammonium sulfate, and the remaining 12 ppm adsorbed by the ash. Although low, but measurable, quantities of $\mathrm{NH}_{3}$ were detected at the EsP 
Table 3-6

FLUE GAS $\mathrm{SO}_{x}$ AND $\mathrm{NH}_{3}$ ANALYSES

\begin{tabular}{|c|c|c|c|c|c|c|}
\hline Date & Time & Location & $\begin{array}{l}\text { Plue Gas } \\
\left({ }^{\circ} \mathrm{F}\right) \\
\end{array}$ & $\begin{array}{c}\mathrm{H}_{2} \mathrm{SU}_{4} \\
(\mathrm{ppm} \mathrm{v} / \mathrm{v}) \\
\end{array}$ & $\begin{array}{c}\mathrm{so}_{2} \\
(\operatorname{ppm} \mathrm{v} / \mathrm{v})\end{array}$ & $\begin{array}{c}\mathrm{NH}_{3} \\
(\mathrm{ppm} \mathrm{v} / \mathrm{v}) \\
\end{array}$ \\
\hline \multirow[t]{9}{*}{$5 / 10 / 83$} & $1058-1111$ & Below $\mathrm{SO}_{3}$ injection & 785 & 10 & 731 & - \\
\hline & $1210-1225$ & Below $\mathrm{SO}_{3}$ injection & 790 & 13 & 799 & -- \\
\hline & & RGP inl & 380 & 0.3 & 638 & -- \\
\hline & $1508-1525$ & ESP inlet & 365 & 0.3 & 676 & -- \\
\hline & & Below $\mathrm{SO}_{3}$ injection & 782 & 14 & 863 & $\ldots$ \\
\hline & $1627-1645$ & ESP inlet & 380 & -- & -- & 0.9 \\
\hline & & Below $\mathrm{SO}_{3}$ injection & 780 & 15 & 853 & -- \\
\hline & $1707-1732$ & ESP inlet & 380 & - & -- & 0.4 \\
\hline & & Below $\mathrm{SO}_{3}$ injection & 784 & 15 & 790 & $\cdots$ \\
\hline \multirow[t]{7}{*}{$5 / 11 / 83$} & $1315-1332^{a}$ & Ahead of air heater & $775-807$ & 3.0 & 886 & - \\
\hline & $1417-1451$ & Ahead of air heater & 816 & 5.9 & 928 & -- \\
\hline & & ESP inlet & 370 & 0.3 & 757 & -- \\
\hline & $1514-1536$ & Ahead of air heater & 824 & 6.8 & 890 & -- \\
\hline & & BGP inlet & 380 & -- & -- & 0.4 \\
\hline & $1600-1638$ & Ahead of air heater & 811 & 5.8 & 841 & - \\
\hline & & ESP inlet & 360 & - & - & 0.5 \\
\hline \multirow[t]{9}{*}{$5 / 12 / 83$} & $0945-1007$ & Ahead of air heater & 842 & 3.4 & 794 & - \\
\hline & $1102-1124$ & Ahead of air heater & 852 & 3.4 & 766 & -- \\
\hline & $1150-1223$ & Ahead of air heater & 854 & 3.4 & 820 & - \\
\hline & & ESP outlet & 390 & 0.2 & 720 & -- \\
\hline & $1300-1315$ & ESP outlet & 390 & 0.4 & 727 & -- \\
\hline & $1328-1349$ & Ahead of air heater & 849 & 3.8 & 802 & - \\
\hline & $1406-1430$ & Ahead of air heater & 845 & 4.5 & 786 & - \\
\hline & & ESP outlet & 390 & -- & - & 0.2 \\
\hline & $1500-1515$ & ESP outlet & 390 & $-\infty$ & - & 0.1 \\
\hline
\end{tabular}

apossible load change during run. 
inlet, it appears that at least 908 of the $\mathrm{NH}_{3}$ (again assuming a 5 ppm injection rate) was removed from the gas phase.

\section{FIVE-STAGE CYCLONE SIZE FRACTIONATION}

A five-stage cyclone system ( 1 ) was used to collect relatively large samples of the fly ash entering the ESP in five discrete size fractions. The objective was to collect as much fly ash as possible in each of the five cyclones, with the size fractionation, extending into the submicron range, for the purpose of laboratory analyses at UNDERC. The cut-points and masses collected in the five cyclones are given in Table 3-7.

Table 3-7

FIVE-STAGE CYCLONE DATA ${ }^{a}$

\begin{tabular}{|c|c|c|c|c|c|}
\hline $\begin{array}{c}\text { Cyclone } \\
\text { No. } \\
\end{array}$ & $\begin{array}{c}\text { Aerodynamic } \\
\text { Cut-Point } \\
(\mu \mathrm{m}) \\
\end{array}$ & $\begin{array}{c}\text { Stcke's } \\
\text { Cut-Point } \\
(\mu \mathrm{m}) \\
\end{array}$ & $\begin{array}{c}\text { Mass } \\
\text { Collected } \\
\text { (mg) } \\
\end{array}$ & $\begin{array}{c}\text { Cum. Mass } \\
<D_{50} \\
(\mathrm{mg}) \\
\end{array}$ & $\begin{array}{c}\text { Cum. }<D_{50} \\
(8)\end{array}$ \\
\hline 1 & 7.46 & 4.79 & $17,433.7$ & $2,693.2$ & 13.38 \\
\hline 2 & 3.45 & 2.20 & $1,596.5$ & $1,096.7$ & 5.45 \\
\hline 3 & 2.53 & 1.60 & 613.6 & 483.1 & 2.40 \\
\hline 4 & 1.06 & 0.659 & 309.6 & 173.5 & 0.862 \\
\hline 5 & 0.573 & 0.346 & 29.5 & 144.0 & 0.715 \\
\hline BUF & - & -- & 144.0 & -- & -- \\
\hline & & Total & $0,126.9$ & & \\
\hline
\end{tabular}

\footnotetext{
acomposite of three runs performed at nearly identical sampling rates. Average flow rate $=1.000$ acfm. Total sampling time $=$ $135 \mathrm{~min}$. Average percent isokinetic $\cong 97 \%$.
}

A total of three runs were performed, one on each day of testing. Total run time for all three runs was $135 \mathrm{~min}$. The sampling rates and calculated cut-points were nearly identical for all three runs, so they were composited as indicated in the table. The size distribution based on the cyclone data is shown in Figure 3-10. 


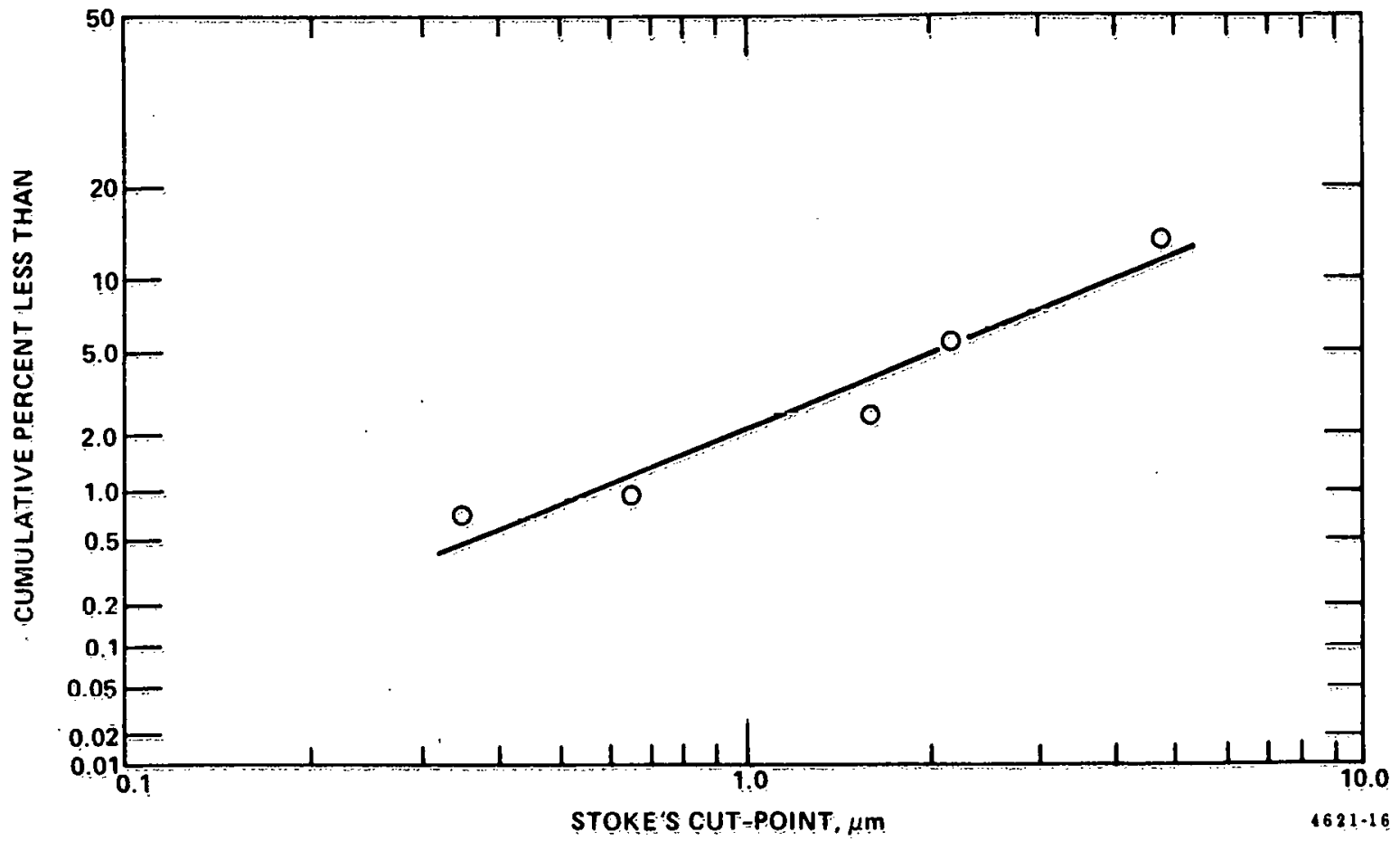

Figure 3-10 Particle Size Distribution Based on Five-Stage Cyclones 
ELECTRICAL CHARACTERISTICS OF ESP

Voltage-current curves were obtained for the ESP 2-1 T-R sets. ESP 2-1 contains four fields: East inlet, West. inlet, East outlet, and west outlet. v-I curves were obtained for all four fields on May 11 and 12, 1983, and are shown in Figures 3-11 through $3-18$.

Figures 3-11 and 3-12 show the V-I curves for the East and west inlet fields on May 11. They are almost identical and are quite well behaved. Figures 3-13 and 314 show the V-I curves for the East and west outlet fields on May 11 . The curve for the East outlet fiela is well behaved, but the curve for the West outlet becomes vertical at about $38 \mathrm{kV}$, indicating electrical breakdown. The achievable current density is still quite high, however. The curves for the inlet fields on May 12 (Figures 3-15 and 3-16) are quite similar to those of May 11 (Figures 3-11 and 3-12), and, again, indicate almost identical electrical performance on both sides of the FSP. On May 12, the cutlet curves appeared similar in shape but the curve for the West outlet was shifted to the left, toward lower voltages, relative to the curve for the East outlet. The breakdown that seemed to occur in the west outlet V-I curve on May 11 was not evident on May 12. 


\section{VDLTAGE CURRENT LURVE \\ BIG BRDWN UNIT - 2 : ESP Z-I

$$
T-R * E R 5 T-I N L E T
$$

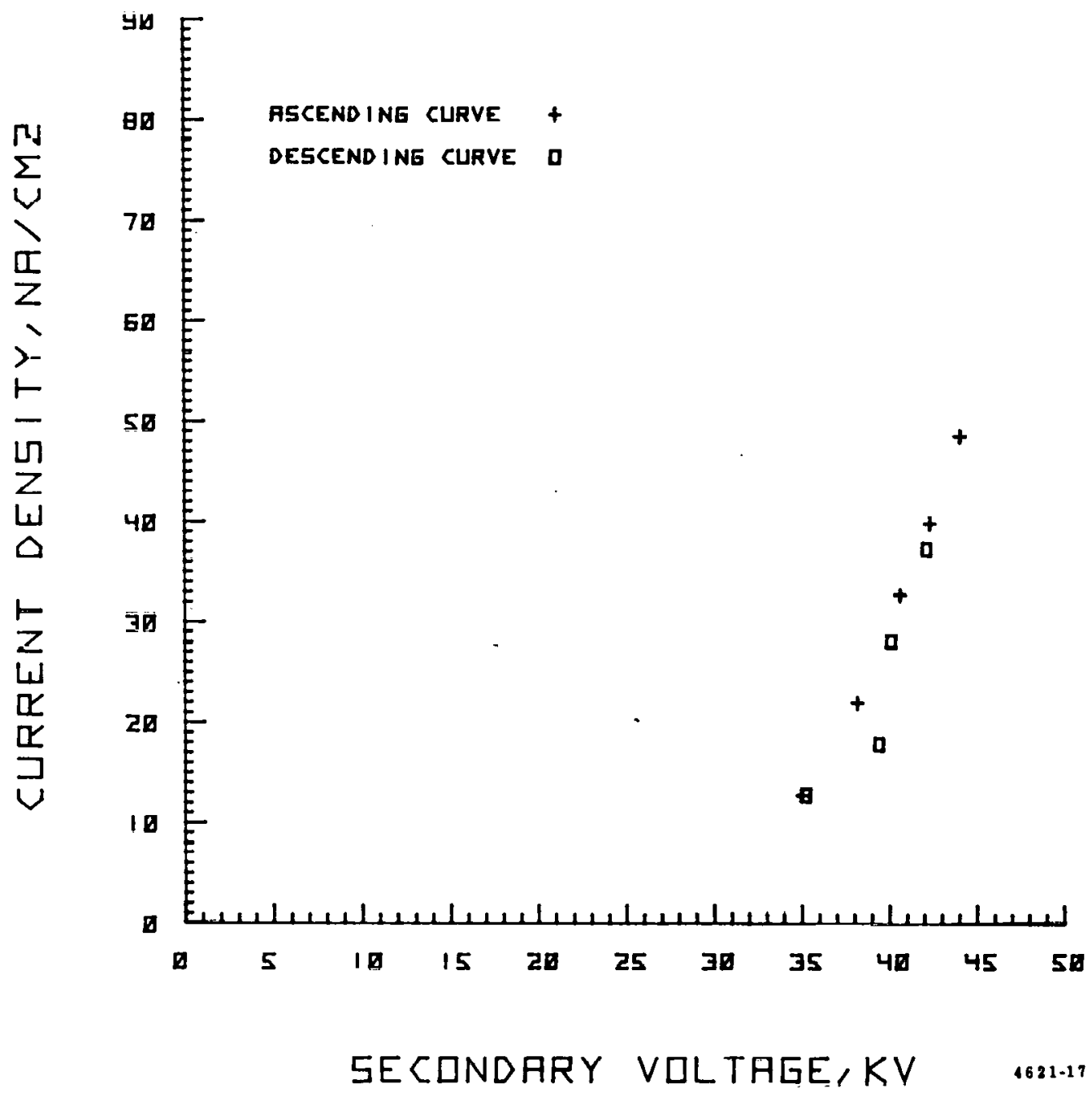

Figure 3-11 Voltage-Current Curve for East Inlet T-R Set on May 11. 1983 


\section{VロLTAGE CURRENT CURVE \\ BIE BRDWN UNIT - 2 : ESP Z-I \\ $T-R \neq$ WEST-INLET \\ $5 / 11 / 83$}

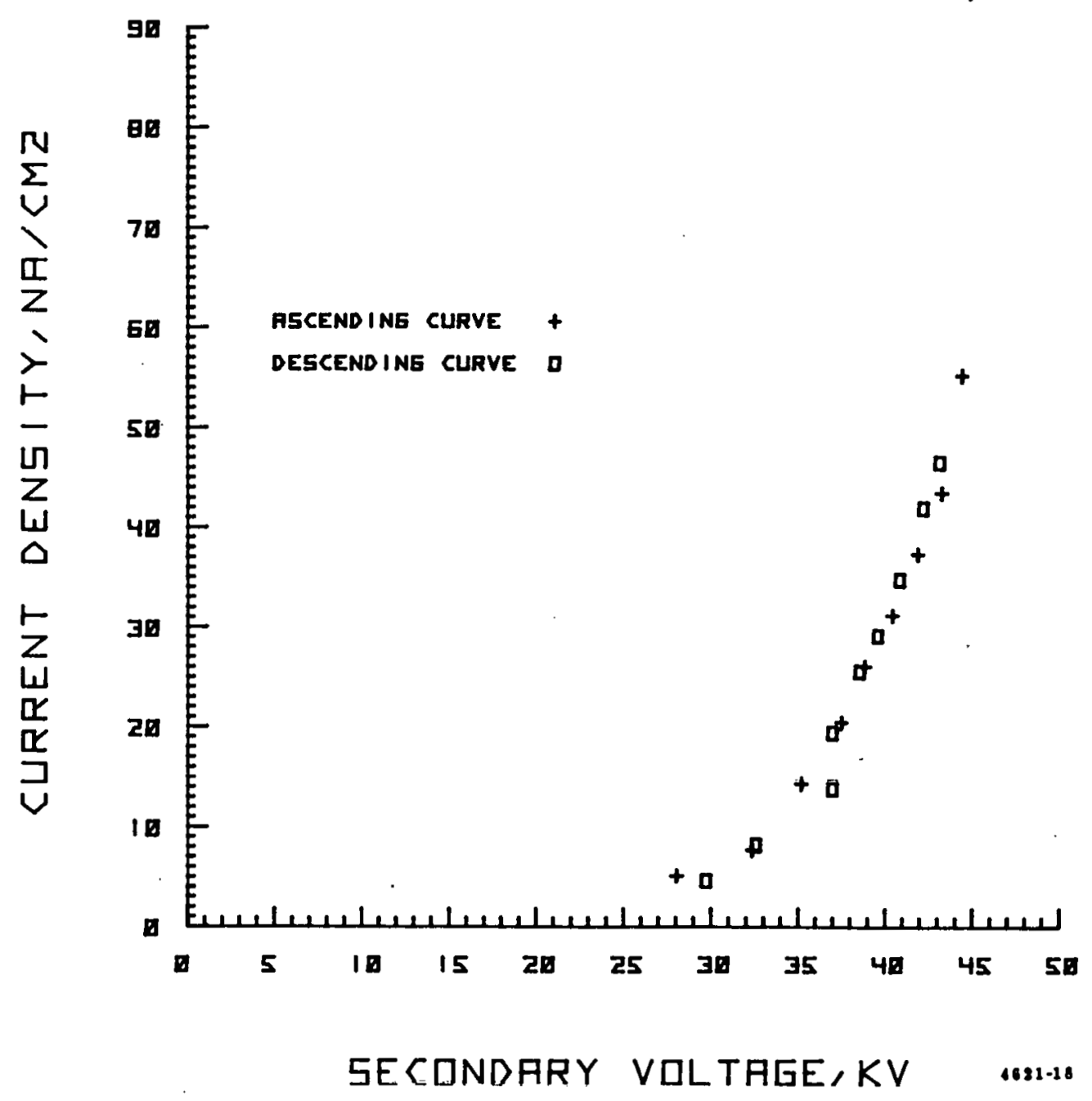

Figure 3-12 Voltage-Current Curve for West Inlet T-R Set on May 11, 1983 


\section{VロLTAБE CURRENT CURVE \\ BIG BRDWN UNIT - Z : ESP Z-I \\ T-R\# ERST-DUTLET $5 / 11 / 83$}

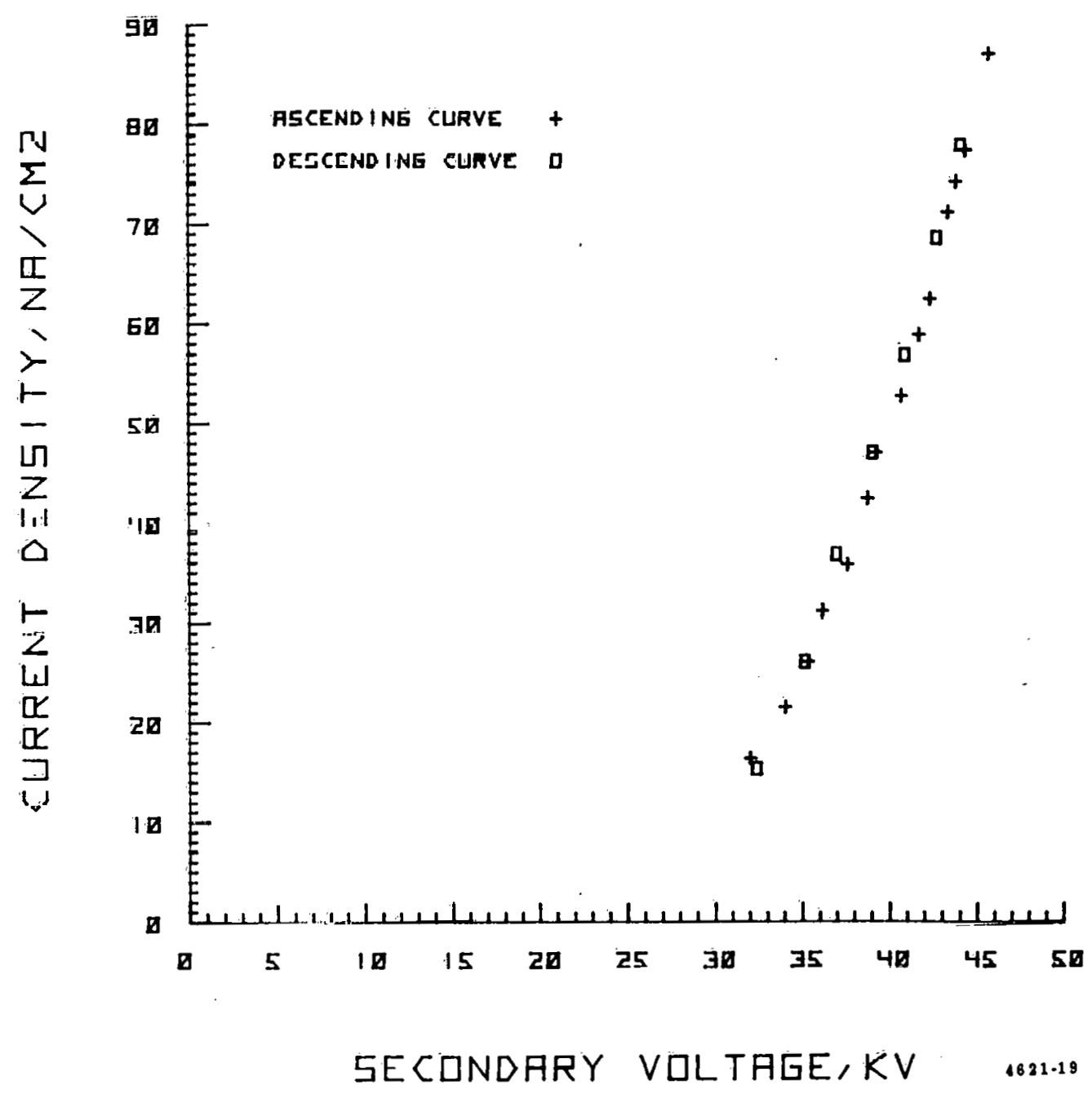

Figure 3-13 Voltage-Current Curve for East Outlet T-R Set on May 11, 1983 


\section{VロLTAGE LURRENT ᄃLRVE BIG BROWN UNIT - Z : ESP Z-I \\ $T-R *$ WEST-QUTLET . $5 / 11 / 83$}

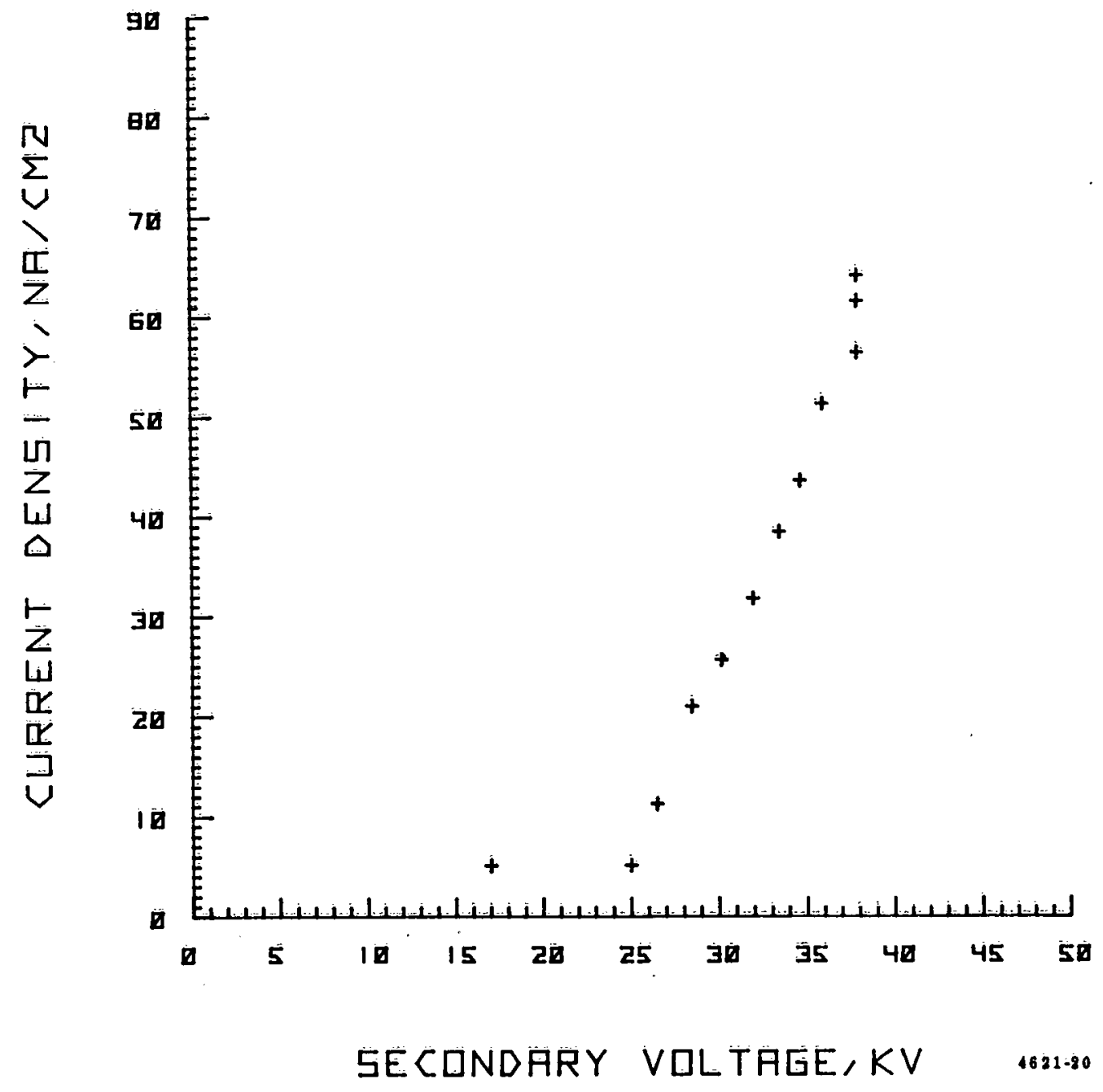

Figure 3-14 Voltage-Current Curve for West Outlet T-R Set on Mav 11, 1983 


\section{VロLTAGE cபRRENT cURVE BIG BRDWN UNIT - Z : ESP Z-I \\ $T-R \vDash E H 5 T-I N L E T \quad 5 / 12 / 83$}

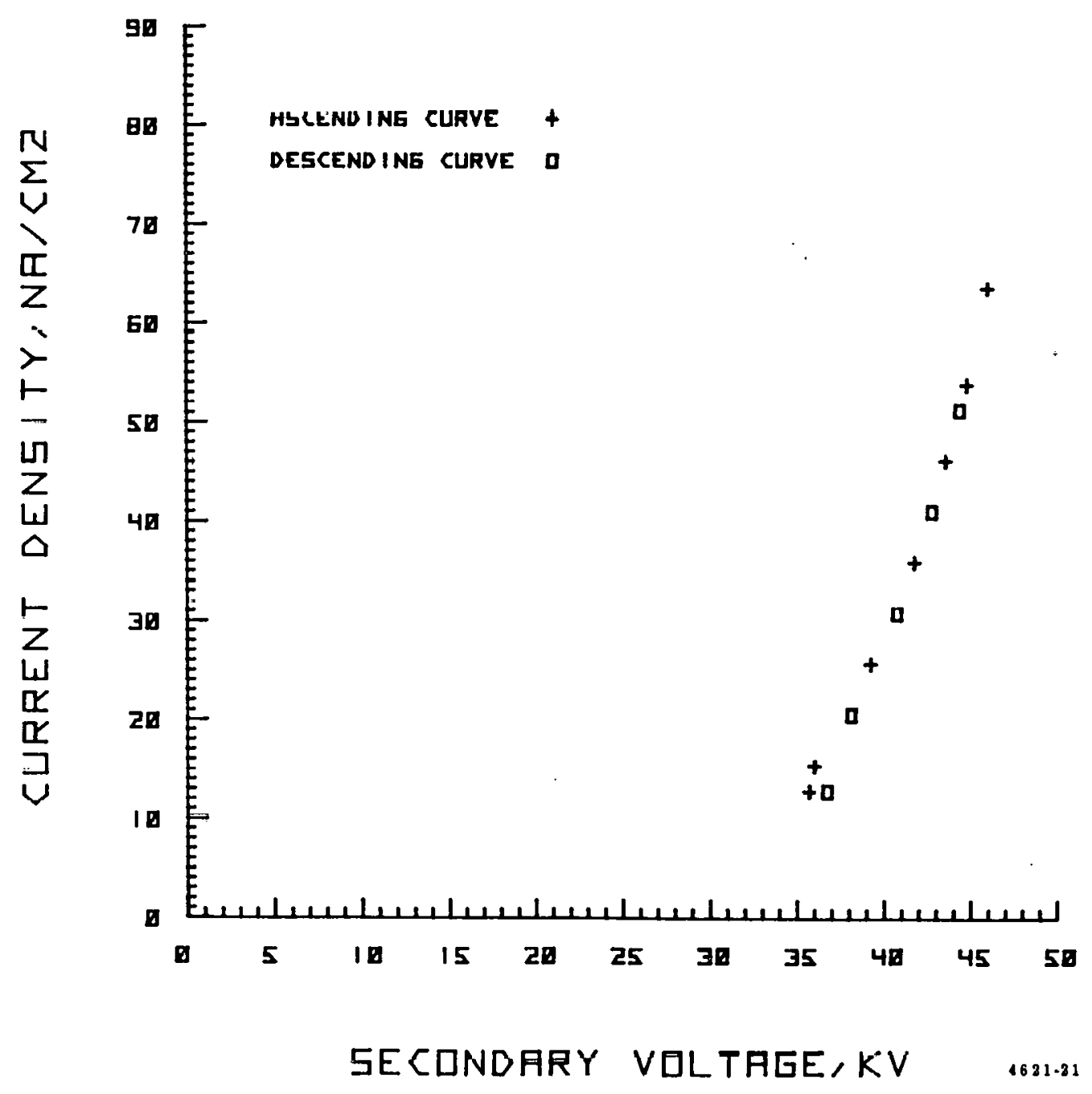

Figure 3-15 Voltage-Current Curve for East Inlet T-R Set on Mav 12, 1983 


\section{VロLTAGE cURRENT CURVE BIE BRDWN UNIT - Z : ESP Z-1 $T-R \neq W E 5 T-I N L E T \quad 5 / 12 / 83$}

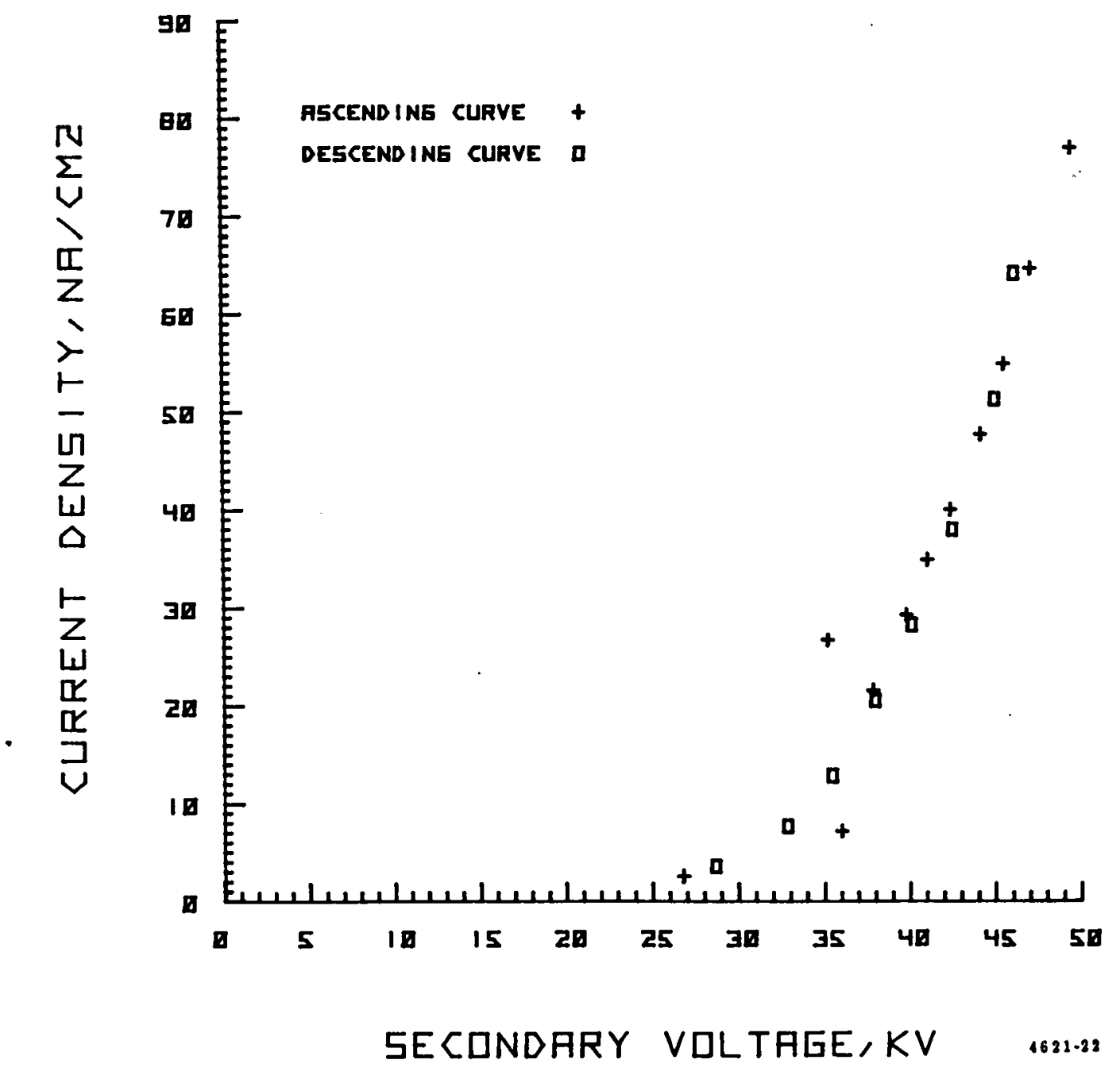

Figure 3-16 Voltage-Current Curve for West Inlet T-R Set on May 12, 1983 


\section{VロLT゙月GE ᄃபRRENT டURVE BIE BROWN UNIT - Z : ESP Z-I $T-R \notin E A T T-D U T L E T \quad 5 / 12 / 83$}

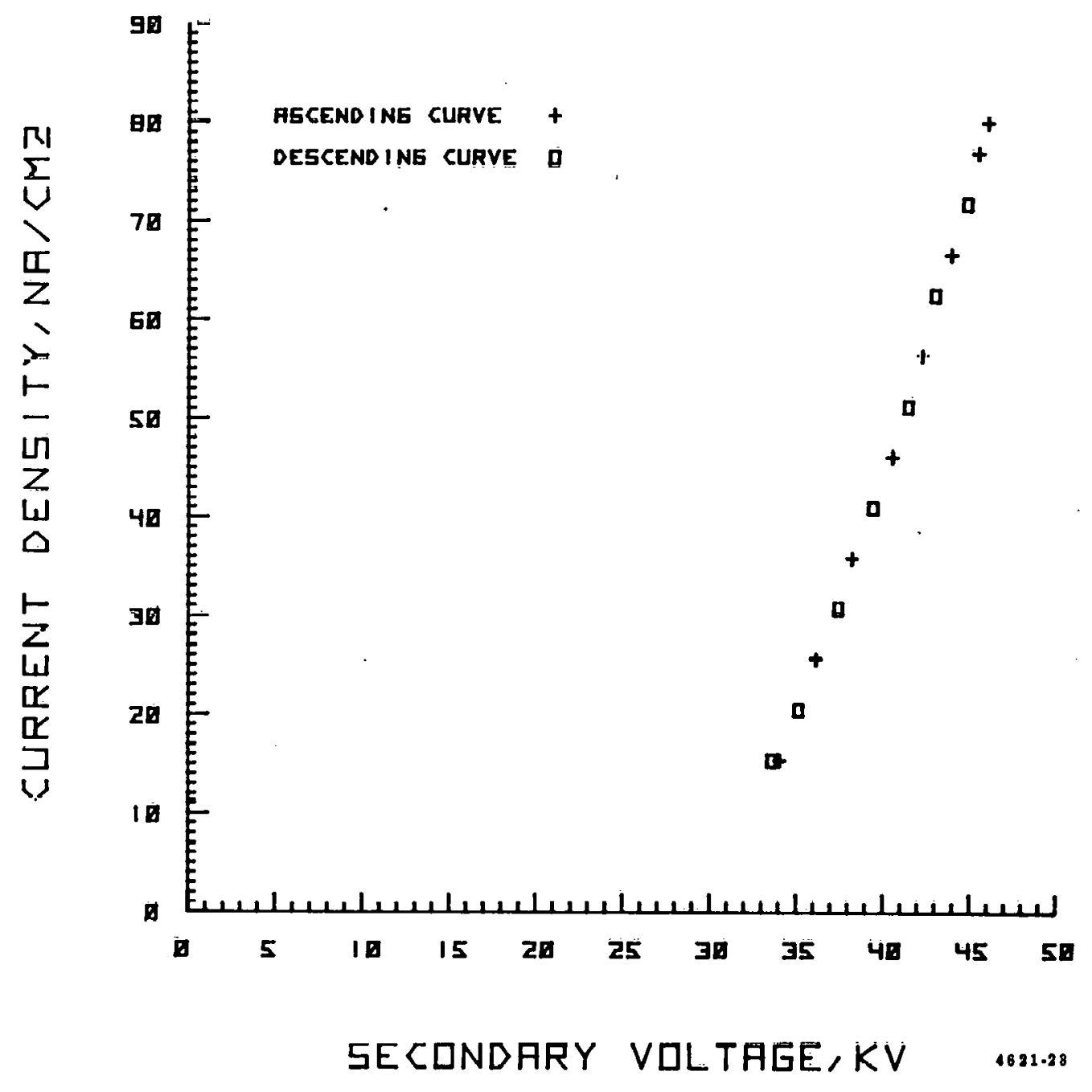

Figure 3-17 Voltage-Current Curve for East Outlet $T-R$ Set on Mav 12, 1983 


\section{VILTAEE CURRENT CURVE}

BIG BRDWN UNIT - Z : ESP Z-1

$T-R \notin$ WEST-QUTLET 5/12/83

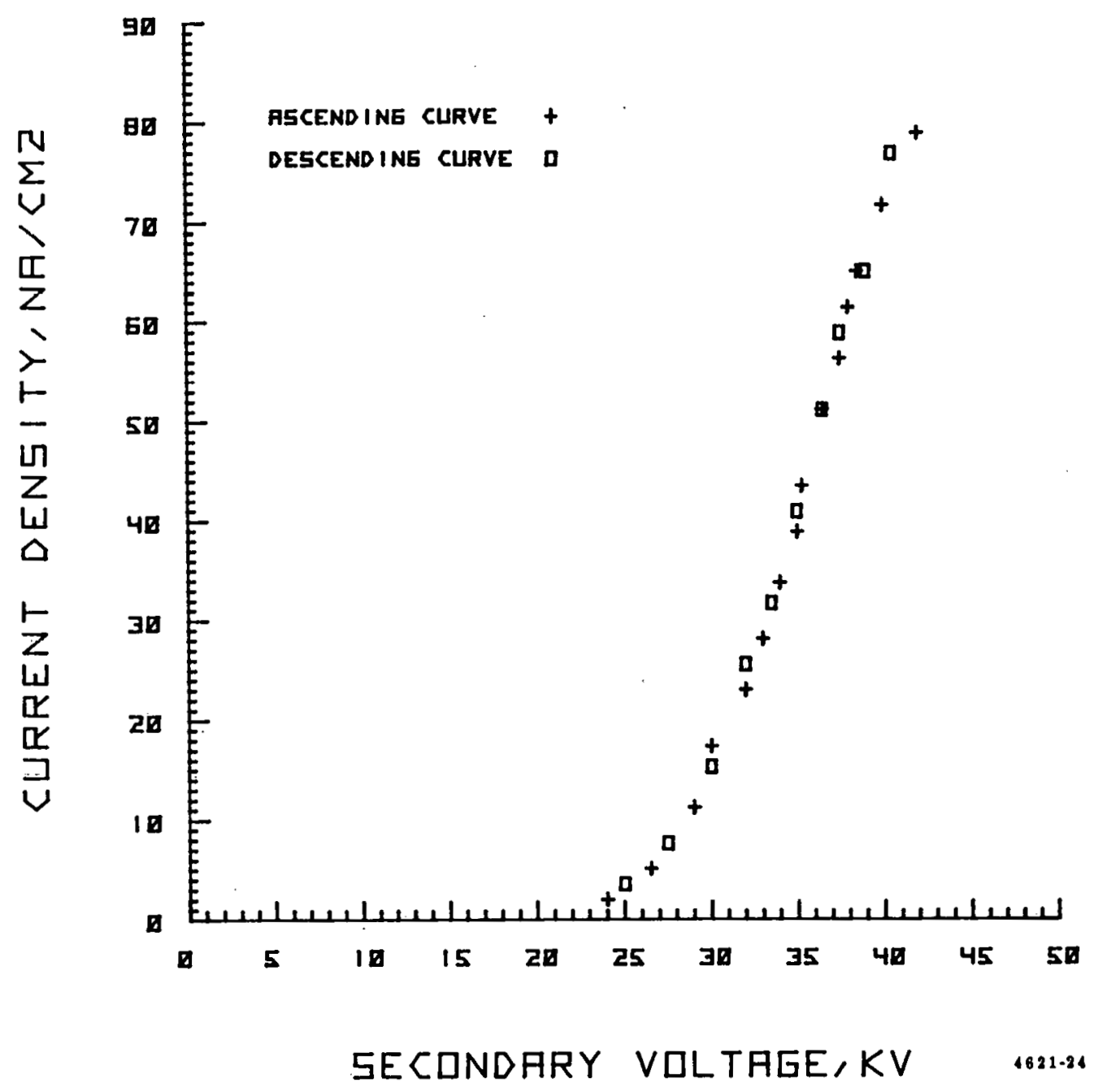

Figure 3-18 Voltage-Current Curve for West Outlet T-R Set on May 12, 1983 


\section{Section 4}

LABORATORY CHARACTERIZATION OF FLY ASH

A fly ash sample taken from an outlet hopper of ESP 2-1 was characterized in terins of its chemical composition, density, Bahco size classification, and electrical resistivity. Normally a proportionately blended hopper sample is used for this examination; however, an inlet hopper sample was not available.

Chemical composition, Bahco particle size classification, and helium pycnometer density data are given in Table 4-1. None of these data are atypical. Because it is an outlet hopper sample, the amount of material smaller than 2 um is high and the concentrations of soluble sulfate and ammonia are greater than the concentrations reported elsewhere for mass train samples. The concentrations of both $\mathrm{NH}_{4}^{+}$and $\mathrm{SO}_{4}^{-2}$ were higher in the outlet hopper sample than in any of the inlet mass train samples. This is to be expected since the outlet hopper sample is biased toward the finer particles, that have high specific surface areas for adsorption of the $\mathrm{NH}_{3}$ and $\mathrm{SO}_{3}$

Normally, resistivity is measured using the IEEE standard 548-1981, descending temperature technique, which starts at $450^{\circ} \mathrm{C}$. Because of the unique flue gas conditioning practice followed at Big Brown, it was reasoned that an ammonium compound could be produced that was intimately associated with the fly ash particles. This could have an effect on resistivity, and a thermal anneal at $450^{\circ} \mathrm{C}$ might destroy the effect. This point is irrelevant if only oulfur trioxide is used. Therefore, resistivity was determined in an environment of air containing 128 water using an ascending temperature procedure starting at $95^{\circ} \mathrm{C}$ and then the descending temperature technique starting at $450^{\circ} \mathrm{C}$. The results are illustrated in Figure 4-1.

The ascending temperature resistivity curve is shown with circular data points and arrows pointing to the right. It is obvious that the ascending data are much lower than the data obtained using the decending temperatuxe technique after the $450^{\circ} \mathrm{C}$ anneal. These data are shown with triangular symbols. 
Table 4-1

PHYSICAL AND CHEMICAL DATA FOR OUTLET HOPPER SAMPLE

$\frac{\text { Chemical Composition }}{\text { a }}$

\begin{tabular}{|c|c|}
\hline $\mathrm{Li}_{2} \mathrm{O}$ & 0.02 \\
\hline $\mathrm{Na}_{2} \mathrm{O}$ & 0.35 \\
\hline $\mathrm{K}, \mathrm{O}^{\mathrm{O}}$ & 0.79 \\
\hline Mg̈o & 3.5 \\
\hline $\mathrm{CaO}$ & 15.7 \\
\hline $\mathrm{Fe}_{2} \mathrm{O}_{3}$ & 6.9 \\
\hline $\mathrm{Al}_{2} \mathrm{O}_{3}$ & 21.2 \\
\hline $\mathrm{SiO}_{2}$ & 48.4 \\
\hline $\mathrm{TiO}_{2}$ & 1.7 \\
\hline $\mathrm{P}_{2} \mathrm{O}_{5}$ & 0.06 \\
\hline $\mathrm{SO}_{3}^{2}$ & 1.6 \\
\hline Total & 100.2 \\
\hline LOI & 0.4 \\
\hline Sol. $\mathrm{NH}_{4}^{+}$? & 0.046 \\
\hline $\mathrm{SOl} \cdot \mathrm{SO}_{4}^{-2}$ & 1.54 \\
\hline
\end{tabular}

Helium Pycnometer Density

Grams/cc - 2.54

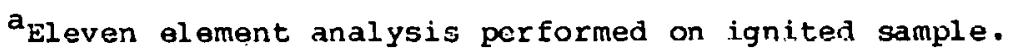

$\begin{array}{lll}\text { LOI } & 0.4 \\ \text { Sol. } & \mathrm{NH}_{4}{ }^{+} & 0.046 \\ \text { Sol. } & \mathrm{SO}_{4}{ }^{-2} & 1.54\end{array}$
Bahco Size Classification

Size $(\mu \mathrm{m})$ Weight \& Less Than

1.3
2.1
4.2
7.8
12.4
21.8
29.0
32.5
MMD $-11.41 \mu \mathrm{m}$
GSD -4.56
$<10 \mu \mathrm{m}-46.548$
(2 $\mu \mathrm{m}=92.578$

5.37

12.31

32.74

46.06

55.06

65.96

70.25

71.87

The ascending test was terminated at $277^{\circ} \mathrm{C}$, slight.ly hel ow the handbook dooompooition temperature of $280^{\circ} \mathrm{C}$ listed for ammonium sulfate. Withnut anplien, unltage, the test cell was held at $277^{\circ} \mathrm{C}$ for $20 \mathrm{hr}$ in the air/water environment. After this, the resistivity had increased from $8.8 \times 10^{9}$ to $3.5 \times 10^{10}$ ohm $\mathrm{cm}$. This resistivity value was still about a factor of 9 lower than the value at $277^{\circ} \mathrm{C}$ for the descending technique data. Apparently the anneal at $450^{\circ} \mathrm{C}$ in dry air for about $16 \mathrm{hr}$ was sufficient to completely remove the remaining effect of the conditioning agent. Excellent agreement was found between the lab-measured data using the descending technique and the predicted resistivity (diamond symbols). The resistivity was predicted by the technique developed by Bickelhaupt ( $\underline{6})$.

Since there is no lasting effect on resistivity due to sulfur trioxide conditioning with respect to laboratory measurements, one concludes that the observed result is associated with the ammonia injection. This same result was observed several years 


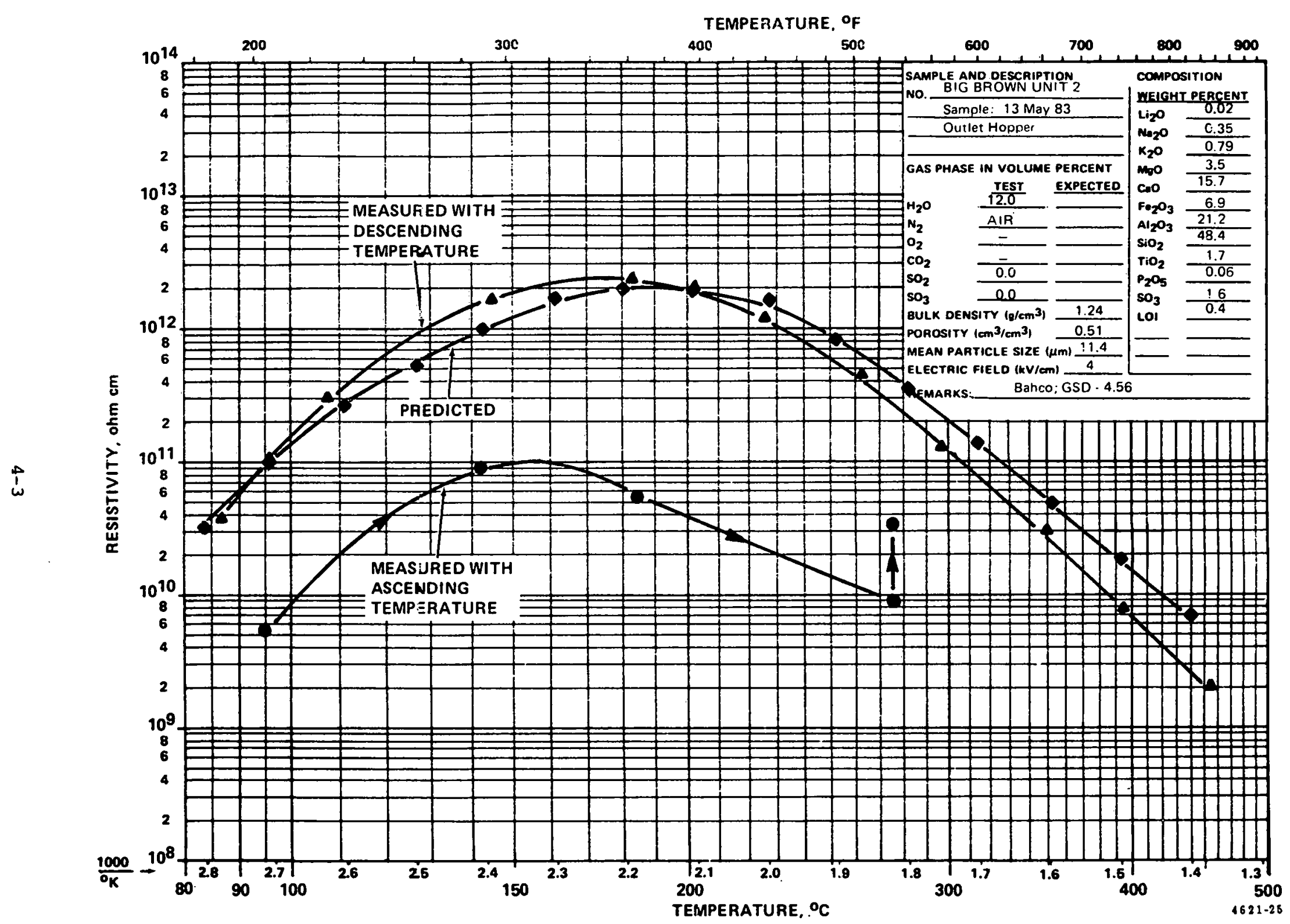

Figure 4-! Resistivity Measurements Made with Ascending and Descending Temperature and Predicted Resistivity as a Function of Temperature 
ago when laboratory measurements were made on another fly ash produced from a high sulfur coal. In this case, ammonia was injected into a flue gas containing a substantial concentration of natural sulfuric acid vapor. In the past, chemical transference experiments were conducted to demonstrate that the ammonium ion can participate in the conduction process. Based on the water scluble ammonium ion data reported in Table 4-1, this sample may contain about 0.28 ammonium sulfate. It is conceivable that this small concentration distributed on the surface of the ash could cause the large difference in ascending and descending resistivity values. Obviously the ammonium ion does not have to be on the surface as the sulfate. $\left(\mathrm{NH}_{4}\right)_{2} \mathrm{SO}_{4}$ may not be the form in which the ammonium ion is present on the surface. Identification of the specific form will require further study.

Since a very small concentration of sulfuric acid vapor $(0.3$ ppm) was deterten at the precipitator inlet, laboratory resistivity determinations were made at $174^{\circ} \mathrm{C}$ in an air environment containing $12 \%$ water and approximately $0.3 \mathrm{ppm}$ of sulfuric acid vapor. These iscthermal tests were conducted with as-received ash and ash that had been equilibrated in dry air at $450^{\circ} \mathrm{C}$ oyernight. The result.s are shnwn in Tahle $4=$ 2 .

Table 4-2

EFFECT OF SULFUR TRIOXIDE ON LAB-MEASURED RESISTIVITY

\begin{tabular}{|c|c|c|c|c|c|}
\hline \multirow{2}{*}{$\begin{array}{l}\text { Temp } \\
\left({ }^{\circ} \mathrm{C}\right) \\
\end{array}$} & \multirow{2}{*}{$\begin{array}{r}\mathrm{H}_{2} \mathrm{O} \\
8) \\
\end{array}$} & \multirow{2}{*}{$\begin{array}{c}\mathrm{SO}_{3} \\
\text { (ppm) }\end{array}$} & \multirow{2}{*}{$\begin{array}{c}E \\
(\mathrm{kV} / \mathrm{cm}) \\
\end{array}$} & \multicolumn{2}{|c|}{ Resistivity (ohm $\mathrm{cm}$ ) } \\
\hline & & & & As-Received & Annealed at $450^{\circ} \mathrm{C}$ \\
\hline 174 & 12.0 & 0.00 & 4 & 1. 1E11 & -- \\
\hline 174 & 12.0 & 0.28 & 4 & $1.4 \mathrm{E} 10$ & -- \\
\hline 174 & 12.0 & 0.28 & 14 & $1.0 E 10$ & -- \\
\hline 174 & 12.1 & 0.00 & 4 & -- & $9.1 \mathrm{E} 11$ \\
\hline 174 & 12.1 & $n, 18$ & 4 & -- & $6.8 E 10$ \\
\hline 174 & 12.1 & 1.18 & 4 & -- & $5.5 \mathrm{E} 10$ \\
\hline Post & st $s$ & le si & te $(8)$ & 1.69 & 1.81 \\
\hline
\end{tabular}

Just prior to electrical breakdown, the resistivity values for the as-rerpiven ash and the annealed sample were $1.0 \times 10^{10}$ and $5.5 \times 10^{10} \mathrm{ohm} \mathrm{cm}$, respectively. These values are much lower than one would expect for such a small acid.concentration at $174^{\circ} \mathrm{C}$. 
Recently unrelated experiments were conducted with a fly ash somewhat similar to Big Brown fly ash in which the acid concentration was $0.3 \mathrm{ppm}$ and the test temperature was about $150^{\circ} \mathrm{C}$. Under these conditions the resistivity was only slightly decreased by thé acid vapor.

In the present case, one can speculate with respect to the as-received sample that the small amount of adsorbed acid has a synergistic effect when coupled with the undefined surface film left on the ash as a result of the dual conditioning process carried out at Big Brown. The very small increase in soluble sulfate (1.698 posttest and 1.548 as-received) is not consistent with the large decrease in resistivity.

Suggesting an explanation for the results observed with the annealed ash is even more difficult. Since the measured resistivity of the annealed ash in an environment of air and water was similar to the predicted values (Figure 4-1), one would expect only a small attenuation of resistivity for the annealed ash due to the presence of $0.2 \mathrm{ppm}$ of sulfuric acid vapor. However, with a small increase in soluble sulfate ( 1.818 post-test and 1.548 as-received), the resistivity decreased by a factor of about 17. It would seem that this ash has some unknown, unique characteristic or the $450^{\circ} \mathrm{C}$ anneal makes the commercially conditioned ash surface inactive with respect to adsorbed water but still active with regard to adsorbed acid vapor.

Figures 4-2 and 4-3 show the predicted resistivity data based on the ash composition given in Table 4-1, 12.08 water, several acid concentrations, and electric field intensities of 4 and $12 \mathrm{kV} / \mathrm{cm}$, respectively. The data from Figure $4-2$ without sulfuric acid present were plotted in Figure 4-1 for comparison with the labmeasured data without acid.

Superimposed on Figure 4-3 are the in situ resistivity data and the lab-measured data for the as-received and annealed ash samples tested with about 0.2 to $0.3 \mathrm{ppm}$ of sulfuric acid vapor, the amount reported for the precipitator inlet. The data are plotted at $174^{\circ} \mathrm{C}$. This was the temperature at the in situ resistivity measurement port. The Iimit bar associated with these data indicates the high and Iow in situ values, and the solid square represents the average in situ value.

At $174^{\circ} \mathrm{C}$, the predicted resistivity value is about $5.0 \times 10^{11}$ ohr $\mathrm{cm}$ for $\mathrm{E}=$ $12 \mathrm{kV} / \mathrm{cm}$ and an environment containing 12.08 water and $0.3 \mathrm{ppm}$ of sulfuric acid vapor. The lab-measured data under these conditions were $5.5 \times 10^{10}$ ohm $\mathrm{cm}$ for the 


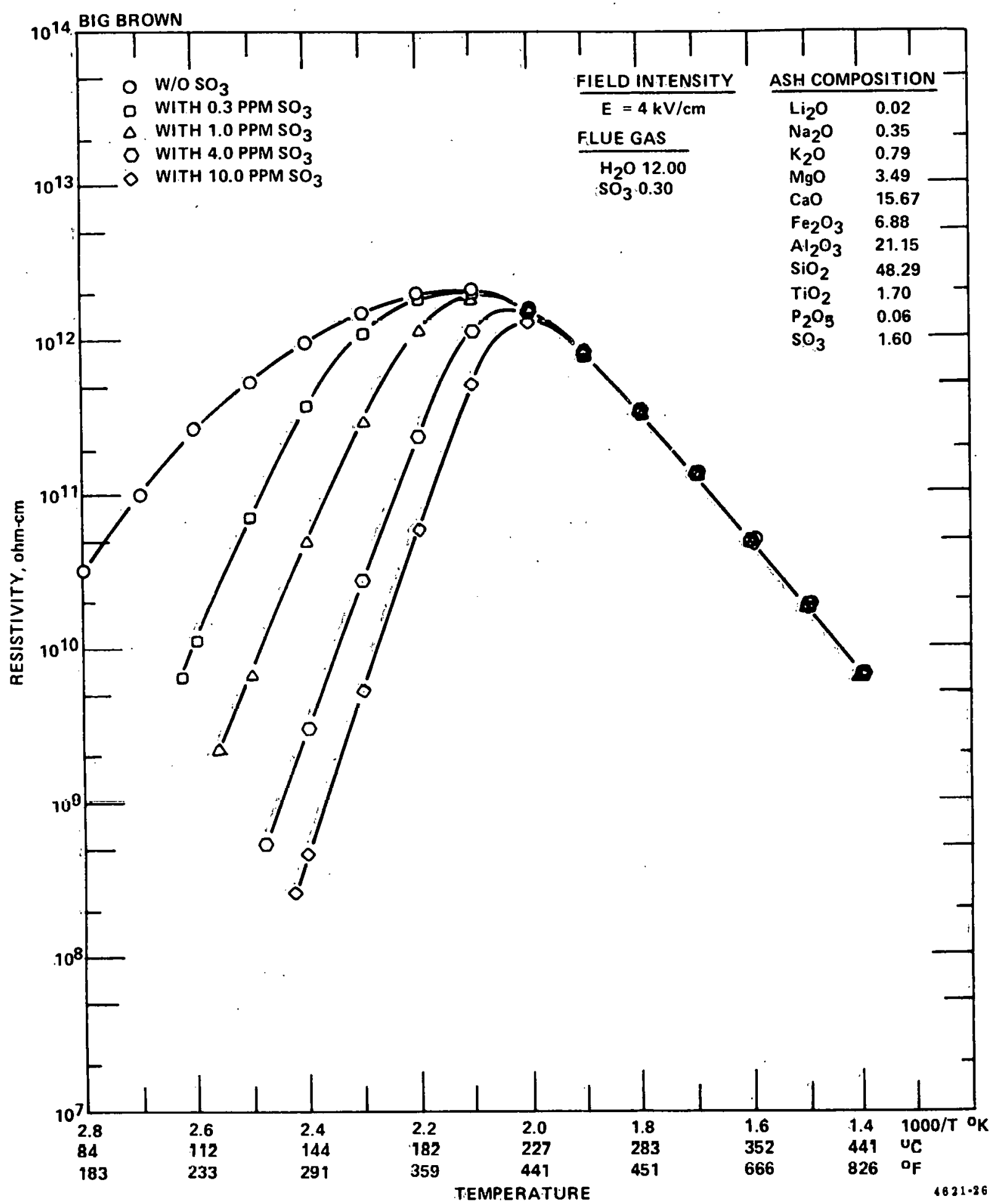

Figure 4-2 Predicted Effect of $\mathrm{SO}_{3}$ on Resistivity at an Electric Field Intensity of $4 \mathrm{kV} / \mathrm{cm}$ 


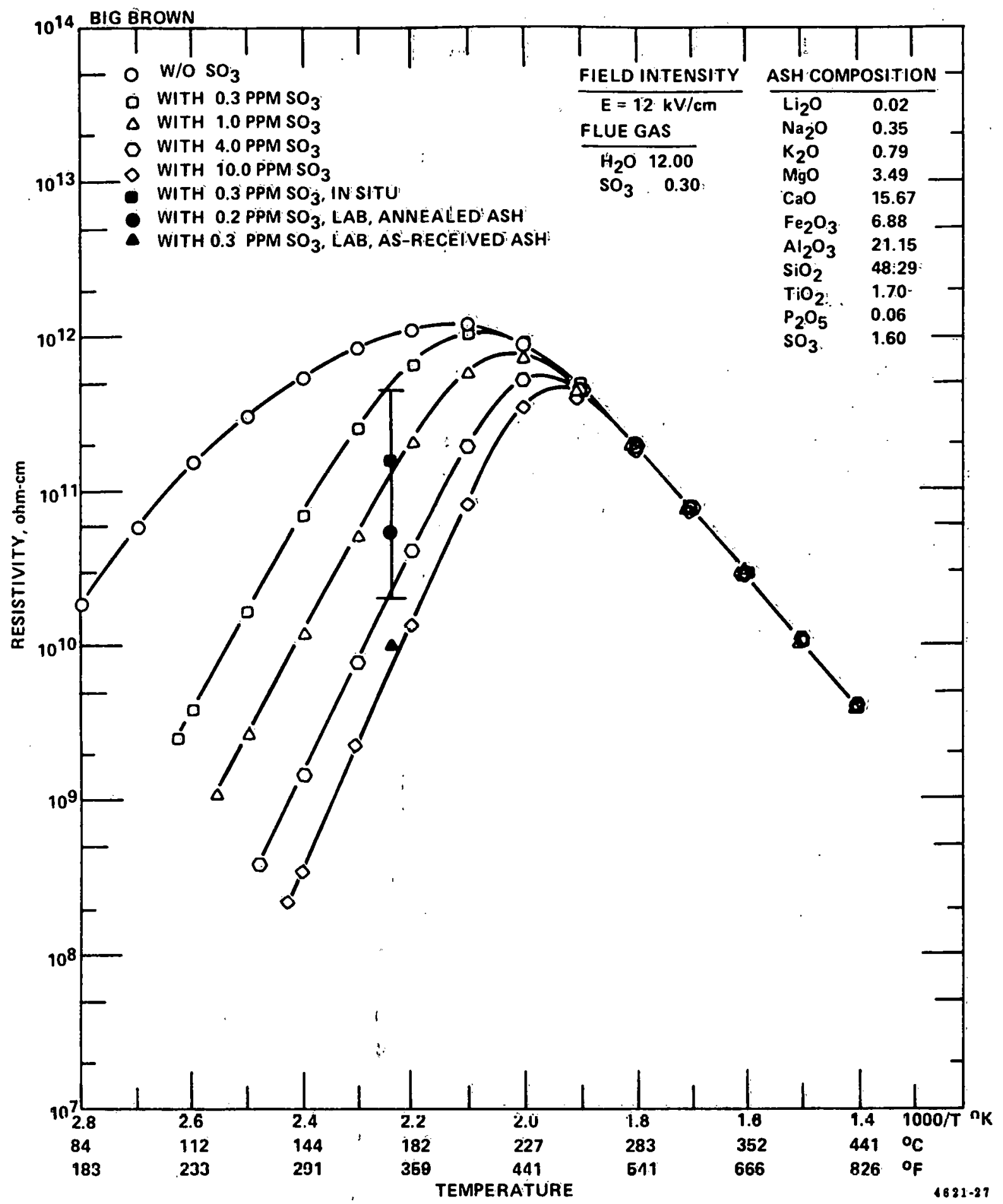

Figure 4-3 In Situ and Laboratory Resistivity Measurements with $\mathrm{SO}_{3}$ and Predicted Resistivity for Various $\mathrm{SO}_{3}$ Leve/s 
annealed sample and $1.0 \times 10^{10} \mathrm{ohm} \mathrm{cm}$ for the as-received sample. It has been suggested above that the lab-measured data are significantly below the predicted value because of the retained effect of the ammonia conditioning at the power station.

Based on the above discussion, the in situ data seem high. Consideration of the data is complicated by the large spread in data from $1.2 \times 10^{10}$ to $4.5 \times 10^{11} \mathrm{ohm}$ $\mathrm{cm}$. Assuning the average in situ value of $1.6 \times 10^{11} \mathrm{ohm} \mathrm{cm}$ is correct, two possible explanations exist to explain why the in situ values are greater than the laboratory data. Perhaps there really isn't $0.3 \mathrm{ppm}$ of sulfuric acid vapor in the gas phase or the concentration was less in the region of the in situ resistivity measurement. Also, it is conceivable that the ash collected in the in situ probe does not contain as much ammonium salt as the ash available to the laboratory. Considering all of these possibilities, it seems more likely that the in situ resistivity data are in exror since they exhibit so much scatter, and they are not consistent with the electrical operation of the ESP or the predicted resistivity values. In view of the scatter in the in situ resistivity data, the laboratory data have been used in this study. 
Section 5

SUMMARY AND CONCLUSIONS

Considering the relatively small size of the Big Brown ESP (SCA $=166 \mathrm{ft}^{2} / \mathrm{kacfm}$ ), its overall performance appears to be quite good. The overall mass collection efficiency for all particle sizes was found to be within the range of 98.22 to 98.778 , with a mean of 98.458. The mean value is in gocd agreement with the overall collecticn efficiency predicted by a semi-empirical computer model of electrostatic precipitation, assuming that 108 of the flue gas bypasses the electrified regions of the ESP and that the standard deviation on the gas velocity profile is equal to 258 of the mean (rins) velocity.

The measurements of collection efficiency versus particle size showed that the Big Brown ESP was also a reasonably good collector of fine particles. The cumulative collection efficiency for all particles smallex than $5 \mathrm{~mm}$, for example, was found to be about $97 \%$.

The voltage-current curves showed good electrical operation in all of the fields of the Big Brown ESP. This is, of course, a direct result of the low resistivity of the Big Brown ash. A resistivity of $1 \times 10^{10} \mathrm{ohm} \mathrm{cm}$ was measured in the laboratory when the as-received ash was equilibrated with the level of $\mathrm{SO}_{3}$ found to be present in the flue gas at the ESP inlet. A much higher value $\left(1.6 \times 10^{11} \mathrm{ohm} \mathrm{cm}\right)$ was obtained from the in situ measurements, but these data are questionable because they are not consistent with the electrical and overall performance of the ESP and the laboratory resistivity data.

The surface film, which is believed to be deposited on the fly ash as a result of the $\mathrm{NH}_{3}-\mathrm{SO}_{3}$ conditioning process, appears to be contributing to the low resistivity of the ash. The hysteresis between the laboratory resistivity curves obtained with ascending and descending temperatures indicates at least an order of magnitude effect of the surface film on the resistivity (i.e., the descending curve was obtained after the ash had been heated to a temperature sufficient to decompose the surface film, and the resultant resistivity value at about $150^{\circ} \mathrm{C}$ was about an order of magnitude higher than the corresponding point on the ascending curvel. The surface film also appears to have a symergistic effect with a small amount of adsorbed 
sulfuric acid (i.e., the resistivity of the as-received ash is attenuated by the equilibration with a given level of $\mathrm{SO}_{3}$ to a greater degree than is the thermally annealed ash in which the surface film has been decomposed). The observations noted above sugqest that the addition of $\mathrm{NH}_{3}$ to the flue gas improves upon the efficacy of the $\mathrm{SO}_{3}$ conditioning.

The combined $\mathrm{NH}_{3}-\mathrm{SO}_{3}$ conditioning process appears to be a feasible and useful method of maintaining acceptable performance levels in a cold-side electrostatic precipitator. Additional work is needed, however, to fully understand the mechanisms by which the $\mathrm{NH}_{3}$ and $\mathrm{SO}_{3}$ act together to condition the fly ash and affect precipitator performance. A more thorcugh investigation of the $\mathrm{NH}_{3}-\mathrm{SO}_{3}$ conditioning process is justified in view of the potential for improving ESP performance, or reducing the size of a new ESP. There is a need for field measurements to be made with and without $\mathrm{NH}_{3}$, $\mathrm{SO}_{3}$, and both agents injected ahead of the ESP. There is also a need for measurements of the effect of $\mathrm{NH}_{3}-\mathrm{SO}_{3}$ conditioning on rapping reentrainment. Further laboratory studies are also needed to elucidate the nature and chemical speciation of the ash surface $\mathrm{film}$ produced by the $\mathrm{NH}_{3}-\mathrm{SO}_{3}$ conditioning process. 
Section 6

REFERENCES

1. 40 CFR 60: 220-237, July 1, 1978 .

2. J. L. Cheney and J. B. Homolya, Environ. Sci. Technol., 13, 584-583 (1979).

3. J. W. Johnson, G. I. Clinard, I. G. Felix, and J. D. McCain, A Computeṛ-Based Cascade Impactor Data Reduction System, EPA-600/7-78-042, March 1978.

4. J. R. McDonald and A. H. Dean, A Manual for the Use of Electrostatic Precipitators to Collect Fly Ash Particles, EPA-600/8-80-025, May 1980.

5. W. B. Smith, R. R. Wilson, and D. B. Harris, Environ. Sci. Technol., 13, 13871392 (19979).

6. R. E. Bickelhaupt, A Technique for Predicting Fly Ash Resistivity, EPA-600/779-204, Auguet 1979. 